\title{
Molecular Details on Multiple Cofactor Containing Redox Metalloproteins Revealed by Infrared and Resonance Raman Spectroscopies
}

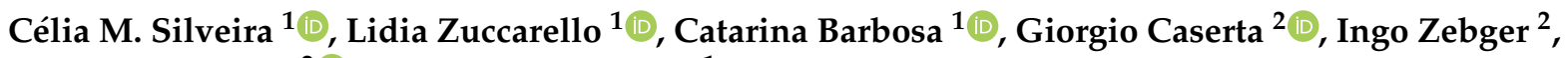 \\ Peter Hildebrandt ${ }^{2}$ and Smilja Todorovic ${ }^{1, *}$ \\ 1 Instituto de Tecnologia Química e Biológica António Xavier, Universidade NOVA de Lisboa, \\ Av. da República, 2780-157 Oeiras, Portugal; celiasilveira@itqb.unl.pt (C.M.S.); \\ lidiazuccarello@itqb.unl.pt (L.Z.); catarina.barbosa@itqb.unl.pt (C.B.) \\ 2 Institut fur Chemie, Sekr. PC14, Technische Universitat Berlin, Strasse des 17. Juni 135, \\ D-10623 Berlin, Germany; giorgio.caserta@tu-berlin.de (G.C.); ingo.zebger@tu-berlin.de (I.Z.); \\ peter.hildebrandt@tu-berlin.de (P.H.) \\ * Correspondence: smilja@itqb.unl.pt; Tel.: +351-214469717
}

Citation: Silveira, C.M.; Zuccarello, L.; Barbosa, C.; Caserta, G.; Zebger, I.; Hildebrandt, P.; Todorovic, S. Molecular Details on Multiple Cofactor Containing Redox

Metalloproteins Revealed by Infrared and Resonance Raman Spectroscopies. Molecules 2021, 26, 4852. https://doi.org/10.3390/ molecules26164852

Academic Editors: Paola Taddei and Michele Di Foggia

Received: 12 July 2021

Accepted: 7 August 2021

Published: 11 August 2021

Publisher's Note: MDPI stays neutral with regard to jurisdictional claims in published maps and institutional affiliations.

Copyright: (c) 2021 by the authors. Licensee MDPI, Basel, Switzerland. This article is an open access article distributed under the terms and conditions of the Creative Commons Attribution (CC BY) license (https:/ / creativecommons.org/licenses/by/ $4.0 /)$.

\begin{abstract}
Vibrational spectroscopy and in particular, resonance Raman (RR) spectroscopy, can provide molecular details on metalloproteins containing multiple cofactors, which are often challenging for other spectroscopies. Due to distinct spectroscopic fingerprints, RR spectroscopy has a unique capacity to monitor simultaneously and independently different metal cofactors that can have particular roles in metalloproteins. These include e.g., (i) different types of hemes, for instance hemes $c, a$ and $a_{3}$ in $c a a_{3}$-type oxygen reductases, (ii) distinct spin populations, such as electron transfer (ET) low-spin (LS) and catalytic high-spin (HS) hemes in nitrite reductases, (iii) different types of Fe-S clusters, such as $3 \mathrm{Fe}-4 \mathrm{~S}$ and $4 \mathrm{Fe}-4 \mathrm{~S}$ centers in di-cluster ferredoxins, and (iv) bi-metallic center and ET Fe-S clusters in hydrogenases. IR spectroscopy can provide unmatched molecular details on specific enzymes like hydrogenases that possess catalytic centers coordinated by $\mathrm{CO}$ and $\mathrm{CN}^{-}$ligands, which exhibit spectrally well separated IR bands. This article reviews the work on metalloproteins for which vibrational spectroscopy has ensured advances in understanding structural and mechanistic properties, including multiple heme-containing proteins, such as nitrite reductases that house a notable total of 28 hemes in a functional unit, respiratory chain complexes, and hydrogenases that carry out the most fundamental functions in cells.
\end{abstract}

Keywords: vibrational spectroscopy; metalloproteins; resonance Raman spectroscopy; IR; heme proteins; Fe-S clusters; hydrogenases

\section{Introduction}

Vibrational spectroscopy has, over the past couple of decades, provided valuable information on structure-function relationship in proteins, contributing to the elucidation of molecular mechanisms, dynamics and interactions on the level that goes beyond high-resolution crystallographic structures. It does not depend on size or paramagnetic properties of the protein like nuclear magnetic resonance (NMR) and electron paramagnetic resonance (EPR) spectroscopies, and furthermore, it can be coupled with electrochemical methods and employed in time-resolved mode, offering the possibility to probe redox and transient molecular events down to the femtosecond time scale [1].

In the case of metalloproteins, the intrinsically low sensitivity and the selectivity of Raman spectroscopy are strongly increased when the energy of the incident laser light is in resonance with an electronic transition of the chromophore. The resultant resonance Raman (RR) spectra display several orders of magnitude higher intensity for the vibrational modes of the cofactor, regardless of the size of the protein matrix [1]. RR spectroscopic studies have 
mainly focused onto metalloproteins containing iron and copper ions, but they have also been reported for other transition metals such as nickel, cobalt, and molybdenum [2-5]. The studies of heme and non-heme iron, iron-sulfur cluster and copper-containing metalloproteins have provided a wealth of details on their active sites, hence contributing to understanding of their mechanistic properties. In particular, RR spectra of heme proteins obtained upon Soret-band excitation are, in the high-frequency $\left(1300-1700 \mathrm{~cm}^{-1}\right)$ region, dominated by the core-size marker bands $v_{\mathrm{i}}\left(v_{4}, v_{3}, v_{2}\right.$ and $\left.v_{10}\right)$ originating from complex porphyrin vibrations that are sensitive to the redox, spin, and coordination state of the heme iron (Figure 1).

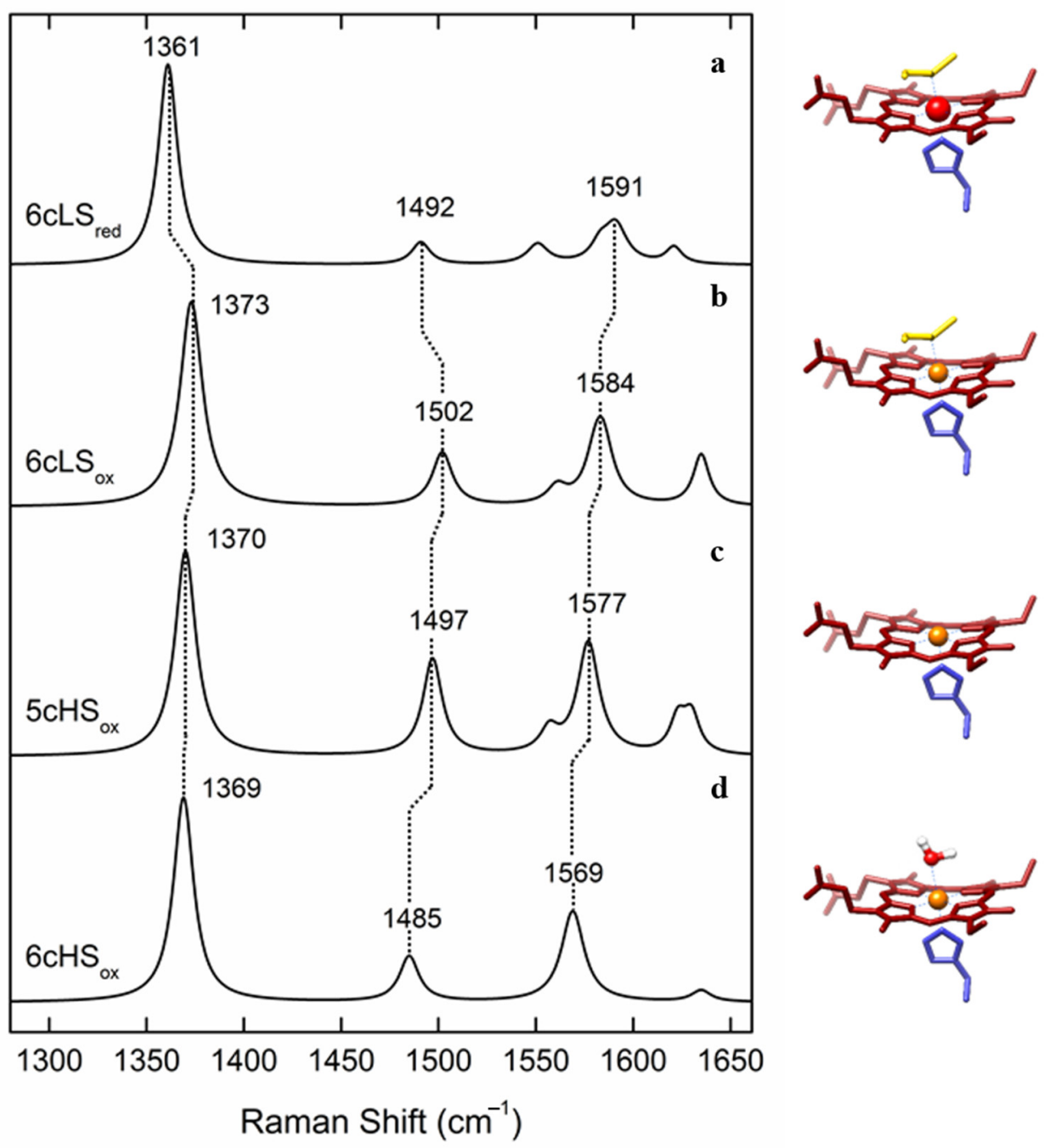

Figure 1. Simulated resonance Raman (RR) spectra of different oxidation, spin, and coordination states of cytochrome $c$, with depicted marker bands, left, and corresponding heme configurations, right. (a) Ferrous $\left(\mathrm{Fe}^{2+}\right.$ ) heme in low-spin (LS) state, coordinated by distal Met and proximal His (6cLS). (b) Ferric $\left(\mathrm{Fe}^{3+}\right)$ heme in 6cLS state, coordinated by distal Met and proximal His. (c) Ferric heme in a high-spin (HS) state, coordinated by proximal His and vacant 6 th axial position $(5 \mathrm{cHS})$. (d) Ferric heme in $6 \mathrm{cHS}$ state, coordinated by a distal water molecule and proximal His.

For instance, a five coordinated high-spin $(5 \mathrm{cHS})$ heme has an increased size of the iron ion in comparison with six-coordinated low-spin LS (6cLS) heme, which is reflected by a frequency downshift of the corresponding $v_{3}$ and $v_{2}$ modes (Figure 1, Table 1) [1] The spectral distinction between LS and HS heme populations is therefore straightforward in RR spectra, which has helped addressing, e.g., processes at catalytic HS vs. electron transfer (ET) LS hemes in oxygen and nitrite reductases and the activation mechanism of cytochrome $c$ peroxidases (CcPs) [6-9]. Similarly, reduction of the heme iron, while 
maintaining the spin and coordination state, causes an increased back-donation of electron density into the $\pi^{*}$ orbital of the ferrous heme porphyrin and thus results in a downshift of the $v_{4}$ mode frequency (Figure 1, Table 1) [1]. The capacity of RR spectroscopy to distinguish between ferric and ferrous heme populations has contributed to disentangling of the ET processes in numerous metalloproteins, as well as those that involve semi-reduced forms of Complex III and dihemic bacterial CcPs $[9,10]$.

Table 1. Assignment of characteristic resonance Raman (RR) and IR active vibrational modes found in metalloprotein. Heme proteins - typical frequency range of the RR marker bands $\left(v_{i}\right)$ of ferric and ferrous His/Met and His/- coordinated $c$-type heme. Iron-sulfur proteins-typical frequency range of predominantly bridging (B) and terminal (T) Fe-S RR modes for different cluster types. Hydrogenases-typical frequency regions of IR and RR bands for metal bound $\mathrm{CO}^{-} \mathrm{Cn}^{-}$ ligand vibrations.

\begin{tabular}{|c|c|c|c|c|c|c|}
\hline & & \multicolumn{5}{|c|}{ Heme Group (1300-1700 cm $\left.\mathrm{cm}^{-1}\right)$} \\
\hline \multicolumn{2}{|c|}{ Coordination and Spin State } & Redox State & $v_{4}$ & $v_{3}$ & $v_{2}$ & $v_{10}$ \\
\hline \multirow{2}{*}{ His/Met } & \multirow{2}{*}{$6 \mathrm{cLS}$} & $3+$ & $1374 \pm 2$ & $1505 \pm 3$ & $1586 \pm 2$ & $1638 \pm 3$ \\
\hline & & $2+$ & $1363 \pm 2$ & $1495 \pm 3$ & $1592 \pm 3$ & $1624 \pm 3$ \\
\hline \multirow{3}{*}{ His /- } & \multirow{2}{*}{$5 \mathrm{cHS}$} & $3+$ & $1371 \pm 2$ & $1496 \pm 2$ & $1576 \pm 2$ & $1627 \pm 4$ \\
\hline & & $2+$ & $1357 \pm 3$ & $1472 \pm 1$ & $1573 \pm 3$ & $1606 \pm 2$ \\
\hline & & \multicolumn{5}{|c|}{ Fe-S Clusters $\left(200-450 \mathrm{~cm}^{-1}\right)$} \\
\hline Cluster & \multicolumn{2}{|c|}{ RR Active Redox State } & \multicolumn{4}{|c|}{ Frequency Range $\left(\mathrm{cm}^{-1}\right)$} \\
\hline $1 \mathrm{Fe}-4 \mathrm{~S}$ & \multicolumn{2}{|c|}{$3+$} & \multicolumn{4}{|c|}{$314-318$} \\
\hline $2 \mathrm{Fe}-2 \mathrm{~S}$ & \multicolumn{2}{|c|}{$2+$} & \multicolumn{4}{|c|}{$281-290(\mathrm{~T})$} \\
\hline $3 \mathrm{Fe}-4 \mathrm{~S}$ & \multicolumn{2}{|c|}{$1+$} & \multicolumn{4}{|c|}{$346-348(B)$} \\
\hline \multirow[t]{2}{*}{$4 \mathrm{Fe}-4 \mathrm{~S}$} & \multicolumn{2}{|c|}{$2+/ 3+$} & \multicolumn{4}{|c|}{ 333-339 (B)/341-344 (B) } \\
\hline & & \multicolumn{5}{|c|}{ [NiFe] and [FeFe] Hydrogenase Active Sites } \\
\hline Hydrogenase & \multicolumn{2}{|l|}{ Bands } & \multicolumn{4}{|c|}{ Frequency Range $\left(\mathrm{cm}^{-1}\right)$} \\
\hline $\mathrm{NiFe} / \mathrm{FeFe}$ & $v(\mathrm{CO})$ & IR & \multicolumn{4}{|c|}{$1780-2030$} \\
\hline $\mathrm{NiFe} / \mathrm{FeFe}$ & $v(\mathrm{CN})$ & IR & \multicolumn{4}{|c|}{$2030-2150$} \\
\hline $\mathrm{NiFe} / \mathrm{FeFe}$ & $\mathrm{Fe}-\mathrm{CN} / \mathrm{CO}$ & $\mathrm{RR}$ & \multicolumn{4}{|c|}{$400-650$} \\
\hline $\mathrm{FeFe}$ & Fe-S [adt] & RR & \multicolumn{4}{|c|}{$300-400$} \\
\hline $\mathrm{NiFe}$ & $\begin{array}{c}(\mathrm{Ni} / \mathrm{Fe})-\mathrm{S} \\
{[\mu \mathrm{Cys}]}\end{array}$ & $\mathrm{RR}$ & \multicolumn{4}{|c|}{$280-400$} \\
\hline $\mathrm{NiFe}$ & $\mathrm{Fe}-\mathrm{OH}[4 \mathrm{Fe}-3 \mathrm{~S}]$ & RR & \multicolumn{4}{|c|}{$500-600$} \\
\hline
\end{tabular}

RR spectra of Fe-S cluster-containing proteins, obtained with a laser wavelength that matches the energy of $\mathrm{S} \rightarrow$ Fe charge transfer (CT) transitions, show selectively enhanced modes involving the metal-ligand stretching coordinates in the low-frequency (200-450 $\mathrm{cm}^{-1}$ ) region (Table 1 ). The spectra are sensitive to the cluster type, structure, and symmetry and moreover allow for distinguishing between bridging vs. terminal Fe-S vibrational modes that predominantly involve inorganic and cysteine-bound $S$ atoms in each cluster, respectively [11]. Unlike in the case of heme proteins, in Fe-S proteins usually only one redox state is RR active; $[2 \mathrm{Fe}-2 \mathrm{~S}]^{2+},[3 \mathrm{Fe}-4 \mathrm{~S}]^{1+}$, and $[4 \mathrm{Fe}-4 \mathrm{~S}]^{2+}$ (and $[4 \mathrm{Fe}-4 \mathrm{~S}]^{3+}$ in HiPIPs). RR spectroscopy can simultaneously probe different types of clusters present in the same protein, alongside with processes that account for their interconversion [11].

Large enhancements of Raman signals are obtained by measuring the spectra of molecules located in close proximity to plasmonic metals (e.g., Ag and Au), due to the surface enhanced Raman (SER) scattering effect [1]. Accordingly, SER spectroscopy can provide sensitive (bio)chemical information about the studied system, representing a promising analytical tool for, e.g., medical diagnostics [12-14]. The combination of the SER and RR effects (SERR spectroscopy) enables sensitive and selective probing of the chromophoric part of molecules, such as the cofactors of metalloproteins attached to SER active metal surfaces [1]. SERR spectroscopy can provide specific molecular information about proteins that perform their physiological function in the immobilized state (e.g., 
membrane proteins). In the case of heme proteins, the conditions for SERR signal enhancement are met upon immobilization on plasmonic Ag structures, for which the surface plasmon energy matches that of the heme Soret electronic transition, when using a laser excitation line around $410 \mathrm{~nm}$. Thus, SERR spectra of heme proteins reveal the oxidation, spin, and coordination states of the heme group, but exclusively of molecules immobilized on plasmonic surfaces. In addition, the nanostructured metal that amplifies the signals can serve as a working electrode, allowing for spectro-electrochemical SERR studies capable of monitoring the changes of the heme group as a consequence of variations of the electrode potential $[1,15]$. This approach can reveal redox potentials $\left(E^{0}\right)$ of distinct and simultaneously present heme groups in immobilized proteins, e.g., $E^{0}$ (HS) vs. $E^{0}$ (LS), which is particularly relevant for understanding of ET pathway in membrane proteins $[6,16,17]$.

Infrared (IR) spectroscopy most commonly provides information on the secondary structure of proteins based on the analysis of the amide I $\left(1600-1700 \mathrm{~cm}^{-1}\right)$ and amide II (1480-1580 $\mathrm{cm}^{-1}$ ) bands [1]. However, when measured in the difference mode, IR spectra can probe structural changes of individual cofactors and sensitively detect redox-linked structural changes, protonation events or amino acids, and specific groups upon isotopic labeling (e.g., ${ }^{13} \mathrm{C}$ and ${ }^{15} \mathrm{~N}$ labeled heme) [18]. Analogous to SERR, surface enhanced infrared absorption (SEIRA) spectroscopy takes advantage of protein molecules that are found in the vicinity of nanostructured metal surfaces deposited on a transmission window or an inert ATR (attenuated total reflection) crystal, experiencing an enhanced absorption of the incident IR radiation. SEIRA can be used to control the protein attachment and orientation at the biocompatible surface upon immobilization, but more importantly it can also provide fine details about redox-linked changes of the secondary structural elements when employed in spectro-electrochemical mode (vide supra) [1,15]. For certain metalloenzymes, where the active site harbors ligands that possess spectrally isolated IR absorption bands, such as hydrogenases, IR (transmission) spectroscopy and its surface sensitive variants offer unique insights in the redox behavior of the catalytic center (Figure 2) [19].

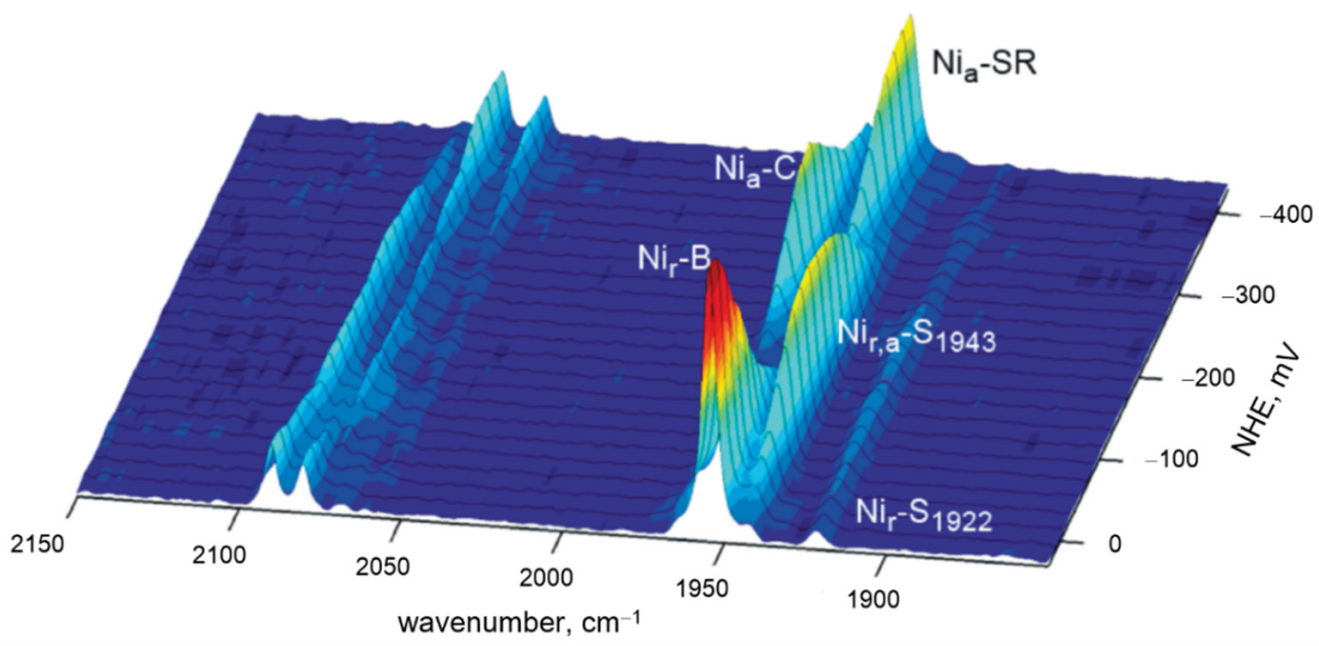

Figure 2. Infrared (IR) potentiometric titration of a [NiFe] hydrogenase in solution, shown in a three-dimensional representation. Each slice represents a spectrum recorded at a designated potential. Redox transition of the active site can be monitored via the characteristic IR absorptions of the CO and $\mathrm{CN}^{-}$ligands between 1920 and $1965 \mathrm{~cm}^{-1}$ and 2050 and $2100 \mathrm{~cm}^{-1}$, respectively. Adapted from Millo et al. [19]. Copyright (C (2009) American Chemical Society. 
[NiFe] and [FeFe] hydrogenases, for example, contain bimetallic catalytic centers with unusual $\mathrm{CO}$ and $\mathrm{CN}^{-}$ligands, exhibiting distinct IR bands related to the corresponding stretching vibrations that are normally centered between 1780 and $2150 \mathrm{~cm}^{-1}$ (Table 1). Their particular frequencies are sensitive to electron density distribution at the bimetallic center. While spectro-electrochemical studies in solution in the transmission mode probe individual redox transitions of the catalytic center and the steps of its activation, as displayed in Figure 2, surface sensitive ATR and SEIRA spectro-electrochemistry allows in situ studies under controlled gas atmospheres and potential control for a better understanding of the activation mechanism and catalysis [19-22].

Here, we review work on several multicofactor redox enzymes, which have been challenging for conventional, e.g., electronic absorption and EPR spectroscopies, and for which vibrational spectroscopy ensured true advancement in understanding of their structural and mechanistic properties. In the following, we (i) discuss multiple hemecontaining proteins, such as nitrite reductases harboring an impressive total of 28 hemes in a functional unit, (ii) describe the work on Complex III and dihemic $\mathrm{C} c \mathrm{Ps}$, the heme groups of which can be distinguished via selective reduction due to large differences in the respective redox potentials, and (iii) dwell on oxygen reductases for which RR and SERR spectroscopy played a crucial role in disentangling the structure and formation kinetics of catalytic intermediates. In the last section, Fe-S-containing proteins, such as hydrogenases and di-cluster-containing ferredoxins, are depicted. The main focus is therefore given to the systems that carry multiple cofactors that can be simultaneously observed in RR spectra, for which in parallel IR spectroscopy can provide further details. The cases in which one of the cofactors has an intrinsically low absorption coefficient and is therefore not observed in (SE)RR spectra, such as the molybdopterin Moco cofactor of human sulfite oxidase that also houses a heme group, will not be discussed [15].

\section{Heme Proteins}

\subsection{Nitrite Reductases (NiR)}

NrfHA menaquinol: nitrite oxidoreductase complex catalyzes the six-electron reduction of nitrite to ammonia in a reaction that involves eight protons. It houses a total of 28 heme groups in the biological unit and, as such, represents a challenge for every experimental approach. Twenty-two heme groups have $6 \mathrm{cLS}$ and six have $5 \mathrm{cHS}$ configuration (Figure 3a); two of the HS hemes are membrane-integrated and the other four represent catalytic sites that carry unusual Lys-coordination. The HS and LS hemes can be easily distinguished in the RR spectra of NrfHA, with redox-sensitive $v_{4}$ and redox/spin-sensitive $v_{3}$ modes of the HS species at 1366 and $1493 \mathrm{~cm}^{-1}$, and of the LS at 1373 and $1501 \mathrm{~cm}^{-1}$, respectively (Figure $3 b$ ), allowing for independent monitoring of the processes that involve these two populations. Binding of nitrite to the catalytic HS hemes and the resulting spin configuration of the initial enzyme/substrate complex have profound consequences for the reaction mechanism of nitrite reduction, indicating whether the $\mathrm{N}-\mathrm{O}$ bond cleavage follows the homolytic or heterolytic route, and the subsequent steps of the catalytic cycle. RR data have provided the first experimental evidence that nitrite binding to NrfHA-active site HS hemes causes a spin conversion from HS to LS configuration, which implies that the heterolytic cleavage of the $\mathrm{N}-\mathrm{O}$ bond is favored in the first step of the catalytic reaction [23]. 
a

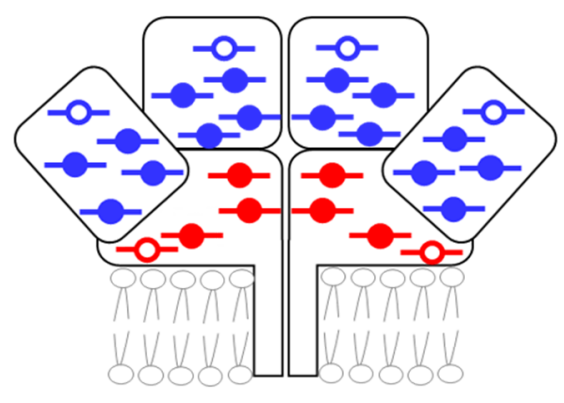

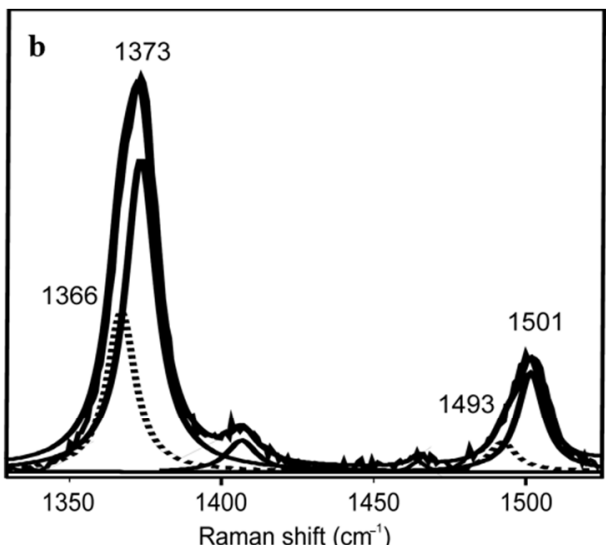

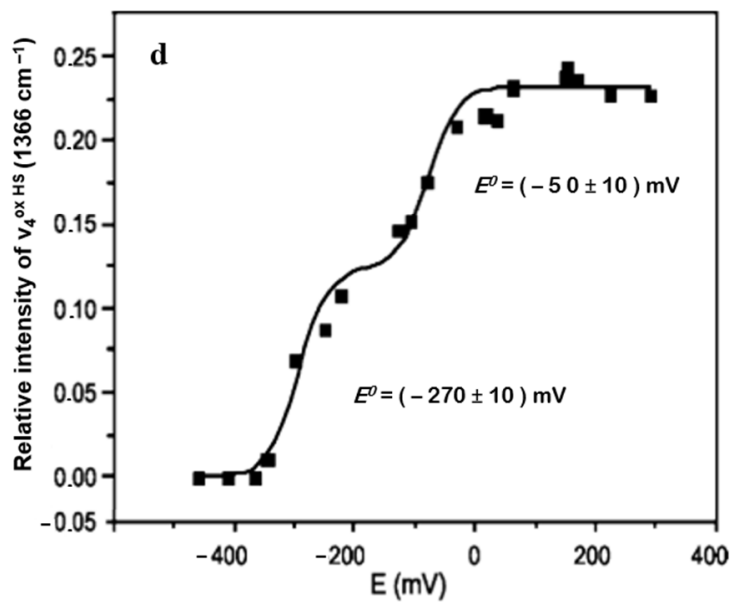

Figure 3. NrfHA nitrite reductase. (a) Schematic representation of 28 heme groups in a functional unit (with LS hemes depicted as solid and HS as empty symbols). (b) High-frequency RR spectrum of ferric NrfHA and its component analysis with designated $v_{4}$ and $v_{3}$ modes of the HS (dotted line) and LS (solid line) species. (c,d) Nernst plots based on variation of $v_{4}$ (HS) along SERR spectro-electrochemical titration of immobilized NrfHA in the (c) presence and (d) absence of 2-n-heptyl-4-hydroxyquinoline N-oxide, HQNO. Adapted from Todorovic et al. [6] and Martins et al. [23]. Copyright (C) $(2010,2012)$ American Chemical Society.

SERR spectro-electrochemistry furthermore helped disentangle the ET pathway in NrfHA. Potentiometric titrations of NrfHA immobilized on biocompatible Ag electrodes was followed by the analysis of the $v_{4}$ band of the HS hemes only $\left(1366 \mathrm{~cm}^{-1}\right)$ in the presence/absence of 2- $n$-heptyl-4-hydroxyquinoline $N$-oxide (HQNO). The inhibitor selectively binds in the proximity of the membrane-integrated HS heme subpopulation (red empty symbols, Figure 3a). Out of the two redox transitions, observed at $E^{0}=-270 \pm 10 \mathrm{mV}$ vs. NHE and at $E^{0}=-50 \pm 10 \mathrm{mV}$ vs. NHE, only the former was modulated in the presence of HQNO (Figure 3c,d). The $E^{0}$ which remained unaltered in the presence of the inhibitor was therefore assigned to the catalytic NrfA HS hemes. These SERR-based insights provided the first evidence for the downhill biological electron flow in the integral NrfHA [6].

Cytochrome $c d_{1}$ nitrite reductases ( $c d_{1} \mathrm{NiRs}$ ) catalyze the reduction of nitrite to $\mathrm{NO}$ as a part of bacterial dissimilatory denitrification pathway. They are homodimer proteins containing a $d_{1}$-type heme in the active site and a $c$-type heme as ET center in each subunit $[24,25]$. Owing to their distinctive electronic absorption properties, the hemes $c$ and $d_{1}$ can be selectively probed by RR spectroscopy employing 413 (or $514 \mathrm{~nm}$ ) and $457 \mathrm{~nm}$ laser excitation, respectively [26-28]. Upon binding of the reaction product, NO, the Soret band of heme $d_{1}$ (ca. $460 \mathrm{~nm}$ ) is blue shifted, allowing for both hemes to be probed with $413 \mathrm{~nm}$ excitation [28]. RR spectra of $c d_{1} \mathrm{NiR}-\mathrm{NO}$ adducts revealed that in addition to 
the heme $c$, two $d_{1}$-heme spin configurations co-exist: a 6 cLS-NO species and a $5 c \mathrm{HS}-\mathrm{NO}$ state, in which the proximal His residue is detached from the heme [28]. The presence of the $5 \mathrm{c}$ adduct was confirmed by a $520 \mathrm{~cm}^{-1}$ mode whose frequency falls in the range of Fe-NO stretching modes characteristic for 5c-NO adducts of $c$-type cytochromes [29-31]. Conversely, the stretching coordinates of the $6 \mathrm{cLS}-\mathrm{NO} d_{1}$ heme have been observed at unusually high frequencies $\left(585 \mathrm{~cm}^{-1}\right.$ in Pseudomonas aeruginosa $\left.c d_{1} \mathrm{NiR}\right)$ in comparison to other heme-NO complexes $[29,30]$, which is thought to be related with the electronic properties and highly ruffled structure of heme $d_{1}$ [27].

\subsection{Heme-Containing Respiratory Chain and Analogous Complexes}

Complex III (ubiquinol: cyt $c$ oxidoreductase or $b c_{1}$ complex) catalyzes the transfer of two electrons from ubiquinol to two cyt $c$ molecules. $b c_{1}$ complexes are formed by a minimum of three subunits, one contains a $c_{1}$-type heme (or structurally and functionally analogous cytochrome $f$ in plants, cyanobacteria, and green algae that house cytochrome $b_{6} f$ complex), one holds a Rieske type [2Fe-2S] cluster, and the third one contains two LS $b$-type hemes, designated $b_{\mathrm{L}}$ and $b_{\mathrm{H}}$ [10]. RR spectroscopy has been employed in the initial characterization of heme groups of the complex at different stages of reduction. Namely, due to the differences in midpoint redox potentials of the heme $c_{1}$, low-potential heme $b$ $\left(b_{\mathrm{L}}\right)$ and high-potential heme $\mathrm{b}\left(b_{\mathrm{H}}\right)$, it is possible to selectively reduce the higher-potential sites (heme $c_{1}$ and $b_{\mathrm{H}}$ ). A selective resonance enhancement using multiple excitation lines and sequential stoichiometric reduction of the complex allowed for spectral distinction between the $c$ and $b$-type hemes, providing insights into the differences in peripheral heme-protein interactions, and in particular the conformation of vinyl substituents of the pyrrole rings [10].

RR spectra of cyt $c_{1}$ - and cyt $f$-containing subunits of $b c_{1}$ and $b_{6} f$ complexes employing Q-band (550 nm) excitation effectively probe the respective local heme environments of these sites, indicating remarkably similar macrocycle geometry of the two hemes [32]. Cyt $b_{6} f$ participates in the oxygenic photosynthesis as a redox link between the two reaction center complexes. RR spectroscopy initially helped identify the chromophoric groups in $b_{6} f$ complexes isolated from different species, revealing a presence of chlorophyll $a, \beta$-carotene, and an additional $5 \mathrm{cHS} c_{1}$-type heme [33]. RR spectra of oxidized, native, ascorbate-and dithionite-reduced forms of spinach cyt $b_{6} f$, obtained using 441, 413, and $406 \mathrm{~nm}$ lasers, reveal RR contributions of chlorophyll $a, \beta$ carotene, the $5 \mathrm{cHS} c$-type heme of cytochrome $f$, and the $b$-type hemes of cytochrome $b_{6}$ of the complex [34]. RR bands arising from the pigments, found in 1520-1575 $\mathrm{cm}^{-1}$ range, are particularly intense in the spectra obtained with $441 \mathrm{~nm}$ [34]. Different conformations of the two $b$-type hemes, a strongly distorted vs. largely planar geometry, were observed and correlated to the differences in the redox potentials of the two hemes in cyt $b_{6} f$, which appears to be a common feature for the $b c_{1}$ and $b_{6} f$ complexes. A functional analogue to $b c_{1}$ complex carrying two $b$-type hemes and one $a$-type heme was found in an archaeon. RR spectroscopy helped characterize the heme groups in this enzyme that show $b c_{1}$ complex activity [35].

IR difference spectroscopic studies of the $b c_{1}$ complex revealed redox-induced structural changes, while additional information obtained on site-directed mutants and sitedirected labeling of cofactors ensured complete assignments of the observed vibrational modes [36]. More recently, ATR-IR spectroscopy was employed to study redox changes in thin layers of bovine $b c_{1}$ complex that have been deposited on the surface of a silicon microprism. Thereby, redox-sensitive IR absorption bands in the potential-induced difference spectra of $c_{1}, b_{\mathrm{H}}$, and $b_{\mathrm{L}}$ hemes, ubiquinone, and surrounding amino acid residues were identified upon selective reduction. A similar approach was used to probe the [2Fe-2S] cluster of the complex. The $\mathrm{pH}$-dependent IR features in the reduced minus oxidized difference spectra revealed specific signals that were attributed to an imidazolate-to-imidazole transition, providing the first experimental evidence that a cluster coordinating His is the most likely candidate for redox-linked protonation site [37,38]. 
Cytochrome c peroxidase, $\mathrm{C} c \mathrm{P}$ : Soluble, periplasmic, dihemic $\mathrm{C} c \mathrm{Ps}$ catalyze the reduction of hydrogen peroxide to water by two electrons delivered from small redox proteins in some bacteria. These $\mathrm{C} c \mathrm{Ps}$ contain two $c$-type hemes, one which is in analogy to Complex III, high-potential, H-heme ( $E^{0}=330$ to $450 \mathrm{mV}$ vs. NHE), and the other low-potential, L-heme ( $E^{0}=-330$ to $-250 \mathrm{mV}$ vs. NHE) in the active site. The resting state of a dihemic $\mathrm{C} c \mathrm{P}$ is typically a catalytically inactive diferric form, with a His- and Met-coordinated H-heme that participates in ET to the active site, and catalytic bis-His coordinated L-heme that requires activation. It is achieved by reduction of the H-heme, which induces $\mathrm{Ca}^{2+}$ dependent spin and coordination change of ferric L-heme to a 5cHS state upon distal $\mathrm{Fe}_{\mathrm{L}}-\mathrm{N}$ (His) bond disruption. RR spectroscopy helped characterize these conformational changes on the level of the two hemes that occur in some $\mathrm{C} c \mathrm{Ps}$ in parallel with those rare CcPs that do not require activation [7-9]. More recently, RR experiments revealed that some CcPs do not follow either of the abovementioned scenarios, as no significant amount of $5 \mathrm{cHS}$ ferric heme population could be detected either in diferric or semi-reduced states. This was rationalized in terms of a novel, more subtle activation mechanism that likely involves formation of a $6 \mathrm{c}$ hydroxo complex, which could react with hydrogen peroxide to create the ferric hydroperoxo complex [7-9].

Oxygen reductase-Complex IV (cyt $c$ : oxygen oxidoreductase, $\mathrm{CcO}$, or heme copper oxygen reductase, or heme copper oxidase, HCO) catalyzes the reduction of molecular oxygen to water by utilizing four electrons and four protons. This is one of the most fundamental reactions in living organisms. HCOs pump protons from the $\mathrm{N}$ to the $\mathrm{P}$ side of the membrane, contributing to the generation of transmembrane electrochemical potential, which drives the ATP synthesis [39]. The catalytic reaction occurs at a binuclear center formed by a HS heme (e.g., heme $a_{3}$ in mitochondrial enzyme, here designated as $\mathrm{CcO}$ ) and a copper atom $\left(\mathrm{Cu}_{\mathrm{B}}\right)$. The ET to the binuclear center is mediated by a LS heme group in the catalytic subunit (heme $a$ in $\mathrm{CcO}$ ) and a copper center in the non-catalytic subunit, which is composed of two copper atoms $\left(\mathrm{Cu}_{\mathrm{A}}\right)$ that hold one redox equivalent (Figure 4a middle). The number of non-catalytic subunits and their cofactors vary in HCOs. Bacteria and archaea have complexes that are simpler than the mammalian $\mathrm{CcO}$, and if required, the expression of the appropriate HCO (e.g., $a a_{3^{-}}, c b b_{3^{-}}$, or $b a_{3^{-}}$type) can be fine-tuned as a function of oxygen pressure levels in the environment. RR spectroscopy played a fundamental role in identification and description of the cofactors in these enzymes, such as (i) the type and spin, oxidation, and coordination state of the heme groups in structurally diverse HCOs of different origin [40-44] and (ii) interactions, conformations, and the dynamics of small ligand $\left(\mathrm{CO}, \mathrm{CN}^{-}, \mathrm{N}_{3}, \mathrm{NO}\right)$ binding [45-51].

The low-frequency region of RR spectra has provided unprecedented details on (i) mechanistic properties of HCOs, including detection and identification of the short living catalytic intermediates formed upon oxygen binding to the catalytic HS heme (i.e., $a_{3}, b_{3}, o_{3}$ ) and (ii) molecular environment and conformation of the catalytic site, based on correlation of Fe-CO and Fe-C-O stretching mode frequencies of HS heme$\mathrm{CO}$ adduct [52,53]. Moreover, protonation events during the catalytic reaction and in particular the role of the two HS heme propionates and the highly conserved amino acid residues found in their vicinity, have been elucidated by RR spectroscopy using structurally different HCOs $[50,54]$, isotopic substitution, wavelength selective resonance enhancement, and mutagenesis studies [55]. A presence of $a$-type hemes in some HCOs offers further advantages as the effect of mutations and other molecular perturbations can be monitored via porphyrin formyl stretching $\mathrm{C}=\mathrm{O}$ modes, which are well resolved in $\mathrm{RR}$ spectra of ferrous HS and LS hemes at 1661 and $1628 \mathrm{~cm}^{-1}$, respectively. In this manner, the frequencies of $a(\mathrm{C}=\mathrm{O})$ and $a_{3}(\mathrm{C}=\mathrm{O})$ stretching modes reveal the respective heme environments [56]. They highlight the importance of $\mathrm{H}$ bonding interactions stabilizing the heme $a$ and hydrophobic environment surrounding the heme $a_{3}$ in an $a a_{3}$-type $\mathrm{HCO}$ and the role of the specific amino acids that participate and ensure a proper environment and H network [54]. 

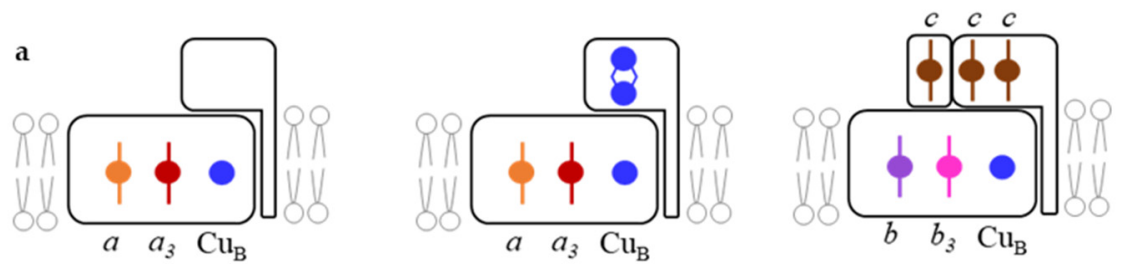

b

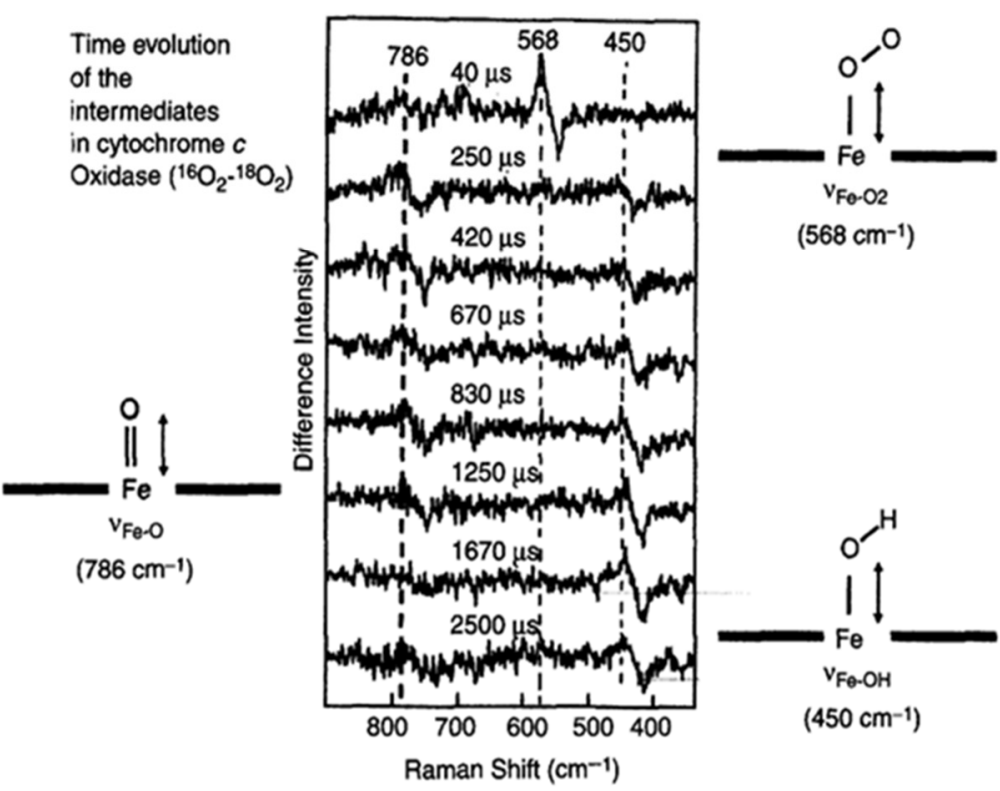

Figure 4. Heme copper oxygen reductases. (a) Schematic representation of cofactors in membraneintegrated catalytic (subunit I) and membrane-anchored non-catalytic subunits in $a a_{3}$ quinol oxidase (QO), mitochondrial $a a_{3}$ cytochrome $c$ oxidase $(\mathrm{CcO})$ and $c b b_{3}$-type $\mathrm{HCO}$. (b) Low-frequency RR spectra of catalytic intermediates of HCOs. Difference RR spectra of $\mathrm{CcO}$ reacting with ${ }^{18} \mathrm{O}_{2}$ and ${ }^{16} \mathrm{O}_{2}$. (b) Adapted from Rousseau et al. [57]. Copyright (C) 2021 Elsevier Science (USA). All rights reserved.

Perhaps the most significant contribution of RR spectroscopy of heme proteins can be attributed to the understanding of the complex catalytic reaction of HCOs, as it provided identification and structural characterization of the transient intermediate species and kinetics of their formation. Reduced HCOs bind molecular oxygen and reduce it via formation of short living A, P, F, and $\mathrm{H}$ intermediates [57], which were initially only tentatively described by electronic absorption spectroscopy. RR experiments performed independently by the groups of Kitagawa, Rousseau, and Babcock led to a consistent mechanistic model of HCOs, employing isotopic labeling, mutagenesis studies, a number of structurally different HCOs, and individually developed TR RR experimental approaches [39,57-61]. In particular, iron-oxygen stretching frequencies obtained by TR RR ${ }^{16} \mathrm{O}_{2}-{ }^{18} \mathrm{O}_{2}$ difference spectra, measured in $\mathrm{H}_{2} \mathrm{O}$ and $\mathrm{D}_{2} \mathrm{O}$ media, helped identify proton-coupled $\mathrm{ET}$ reactions and establish structural fingerprints of each catalytic intermediate (Figure $4 \mathrm{~b}$ ). These include the first formed compound A, assigned to ferric-superoxide species with ironoxygen stretching frequency at $568 \mathrm{~cm}^{-1}$, compound P (iron-oxygen stretching frequency at $804 \mathrm{~cm}^{-1}$, electronic transition at $607 \mathrm{~nm}$ ), and compound F (iron-oxygen stretching frequency at $786 \mathrm{~cm}^{-1}$, electronic transition at $580 \mathrm{~nm}$ ). The $\mathrm{P}$ and $\mathrm{F}$ are both attributed to oxoferryl, $\mathrm{Fe}^{4+}=\mathrm{O}$, species with subtle differences in the proximal His ligand of $a_{3}$ and one of its propionates, and/or the presence of a nearby amino acid (Tyr) radical [57,62]. The intermediate $\mathrm{F}$ decays into hydroxyl $\mathrm{H}$ species, with $\mathrm{Fe}-\mathrm{OH}$ stretching frequency of $450 \mathrm{~cm}^{-1}$, Figure $4 \mathrm{~b}$.

IR difference spectroscopy recorded under steady state conditions and in the TR mode identified protonation/deprotonation and re-protonation events during the catalytic cycle of $a a_{3}$-type HCO. The data in particular point out the role of a proton shuttle of glutamic 
acid found at $\sim 11 \AA$ from the active site, which changes its protonation state a number of times during the catalytic cycle. The role of the Tyr located in the proximity of the binuclear center in the splitting of the O-O bond during the catalysis was also highlighted by IR spectroscopy [63].

More recently, SERR spectroscopy provided a novel platform for investigations of HCOs under conditions that can mimic some basic features of their natural environment. Since these enzymes exert their function integrated into a phospholipid bilayer under restricted mobility, directionalized ET from electron donor to LS heme and binuclear site, and influence of strong interfacial electric fields, the immobilization onto biocompatible electrodes mimics far better these conditions than the solution studies [16]. Furthermore, SERR potentiometric titrations represent a powerful alternative to common methods for the determination of the $E^{0}$ value, which is a prerequisite for understanding the ET pathway in these enzymes. The determination of $E^{0}$ of the individual heme groups of HCOs by conventional electronic absorption titrations is hampered by strong overlapping of the spectra of individual hemes and by complex cooperative effects that modulate the electroprotonic energy transduction [16]. To that end, an $a a_{3}$-type quinol oxidase $\left(a a_{3} \mathrm{QO}\right)$ that contains the catalytic and one cofactor-free non-catalytic subunit (Figure 4a) was attached to detergent-coated Ag electrodes by spontaneous adsorption. A comparison of RR and SERR spectra of the enzyme in solution and adsorbed states revealed that the enzyme preserved its native structure upon immobilization (Figure 5a). Deconvolution of the (SE)RR spectra by component analysis (Figure $5 b, c$ ) allowed separation of the contributions from the LS and the HS hemes based on their respective $v_{3}$ and $v_{\mathrm{C}=\mathrm{O}}$ modes, among more than 40 vibrational modes originating from the two hemes [16]. The potential dependence of these spin- and redox-state-sensitive marker bands allowed for determination of midpoint redox potentials of hemes $a\left(E^{0}=320 \mathrm{mV}\right.$ vs. NHE) and $a_{3}\left(E^{0}=390 \mathrm{mV}\right.$ vs. NHE), which reveal a reversed order of reduction compared to mitochondrial-like HCOs. This suggests a distinct mechanism of electroprotonic energy transduction in $a a_{3} \mathrm{QO}$ in comparison with, e.g., $\mathrm{CcO}$ (Figure $5 \mathrm{~d}$ ). A downhill ET is already guaranteed by the order of the midpoint redox potentials at the onset of enzyme reduction, indicating that this enzyme does not require a complex network of cooperativities to ensure exergonicity. Another SERR study employed a more complex, pentahemic $c b b_{3}$-type HCO, anchored to nanostructured Ni-NTA-coated Ag electrodes and further embedded into a lipid bilayer that mimics the natural membrane, which was catalytically active within the electrode construct [64]. This strategy, which allows the control of the enzyme orientation that can be probed by SEIRA spectroscopy, was first developed in the studies of $a a_{3}$-type HCO $[17,65,66]$. SERR potentiometric titrations of the whole $c b b_{3}$-type HCO complex and of the two individually expressed non-catalytic subunits, indicate that the dihemic subunit can be considered redundant for ET and catalysis, supporting the hypothesis that it plays a role in oxygen sensing. SERR also helped clarify the poorly understood coupling between heme reduction and proton translocation in HCOs and in particular the involvement of heme $a_{3}$ propionates in the proton pumping. The analysis was based on the protonation dependent $\mathrm{CH}_{2}$ propionate bending modes that have been detected by $\mathrm{H}_{2} \mathrm{O}-\mathrm{D}_{2} \mathrm{O}$ (SE)RR difference spectroscopy. This allowed individual assignment of all four heme propionates. The data support the hypothesis that heme $a_{3}$ propionates act as possible proton loading sites in HCOs [67]. 

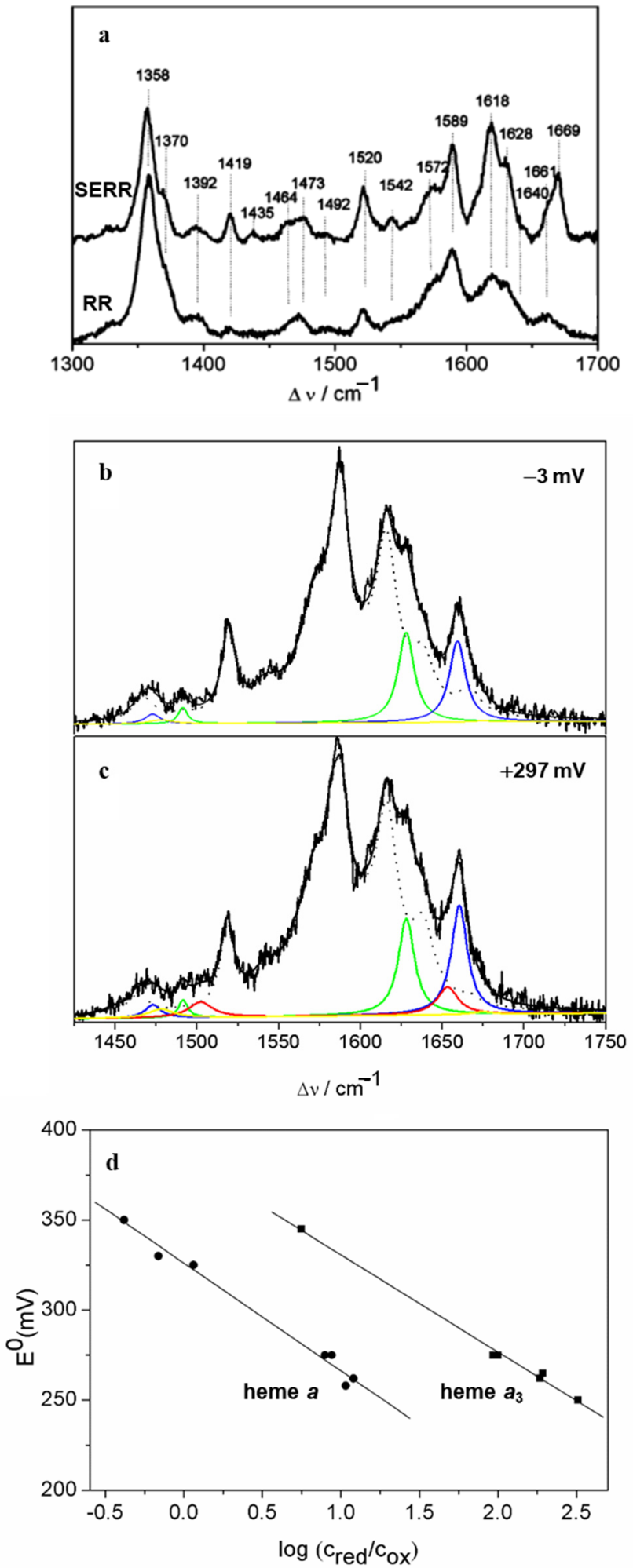

Figure 5. $a a_{3}$ quinol oxidase (QO). (a) SERR spectrum of ferrous QO immobilized on Ag electrode at a potential of $-403 \mathrm{mV}$ vs. NHE and RR spectrum of QO in solution reduced with dithionite. $(\mathbf{b}, \mathbf{c})$ SERR spectra of the immobilized QO at electrode poised potential of (b) -3 and (c) $+297 \mathrm{mV}$ vs. NHE; component spectra represent the overall simulated spectra (black), ferrous heme $a$ (green), ferric heme $a$ (yellow), ferrous heme $a_{3}$ (blue), ferric heme $a_{3}$ (red), and the envelope containing all other bands common to hemes $a$ and $a_{3}$ (dotted black). (d) Nernst plots for the redox processes of immobilized QO. Adapted from Todorovic et al. [16]. Copyright ( () (2005) American Chemical Society. 
IR difference spectroscopy was employed to specifically probe the heme propionate protonation events using a $\mathrm{CcO}$ mutant with ${ }^{13} \mathrm{C}$ labeled propionates to distinguish its signal from possible concomitant changes of $\mathrm{CO}$ stretching modes of carboxylic acid groups of side chains [18]. In such a way, differential IR spectra, employing isotopically labeled ligands or different redox states of the protein (e.g., oxidized minus reduced), provided further structural details on active site conformations in HCOs and specific protonatable sites $[68,69]$. It was demonstrated that $\mathrm{NO}$ binding to $c b b_{3}$, which also efficiently reduces $\mathrm{NO}$ to $\mathrm{N}_{2} \mathrm{O}$, exclusively occurs via $\mathrm{HS}$ heme $b_{3}$, and not via $\mathrm{Cu}_{\mathrm{B}}$ as suggested [70]. Step-scan IR spectroscopy, using $\mathrm{Cu}_{\mathrm{B}}-\mathrm{CO}$ adduct as a probe, showed that the protonation events in the binuclear site of $b a_{3}$-type $\mathrm{HCO}$ involve Tyr residues [71]. Moreover, electrochemical redox titrations of $a a_{3}$ - and $c a a_{3}$-type HCOs, performed using IR spectroscopy in the transmission and the ATR mode, helped identify the redox-sensitive bands originating from heme groups, their ligands, amino acid residues and/or protein backbone. This strategy allowed for tentative assignment of the redox transitions of the individual redox centers [36,68,72]. A similar approach, in which electrochemistry coupled to redox induced IR difference spectroscopy was used to address the $E^{0}$ of the heme $b_{3}$ in $c b b_{3}$ HCOs, revealed relatively low midpoint redox potential of this HS heme. It was rationalized in terms of a unique coordination scheme involving hydrogen bonding between the His ligand of the heme $b_{3}$ and a highly conserved glutamic acid, which participate in coupled electron and proton transfer steps and facilitate ET between LS and HS hemes during turnover [73].

Nitric oxide reductase (NOR) catalyzes the two-electron reduction of $\mathrm{NO}$ to $\mathrm{N}_{2} \mathrm{O}$ at the di-nuclear heme $b_{3}-\mathrm{Fe}_{\mathrm{B}}$ center. Similarly to the active site of HCOs, the heme $b_{3}$ is in the HS state, while $\mathrm{Fe}_{\mathrm{B}}$ is a non-hemic iron atom. NORs in addition house $c$-type and $b$-type LS hemes. RR spectroscopy provided evidence about NO reduction by monitoring the events that occur upon NO binding to the catalytic $b_{3}$-type heme. Specifically, formation of the $\mathrm{N}-\mathrm{N}$ bond and the fate of the proximal His-heme $b_{3}$ bond along this process, as well as the recovery of the $b_{3}-\mathrm{O}-\mathrm{Fe}_{\mathrm{B}}$ state, have been disentangled by RR spectroscopy [74].

\section{Fe-S Proteins}

\subsection{Hydrogenases}

Hydrogenases catalyze the reversible splitting of molecular dihydrogen $\left(\mathrm{H}_{2}\right)$ into protons and electrons (or hydride species), often with high catalytic rates, and can be classified into [NiFe], [FeFe], and [Fe]-hydrogenases, depending on the particular metal composition of their catalytic centers [75]. These metalloenzymes have been extensively studied in recent years, revealing new insights into the mechanistic details of the $\mathrm{H}_{2}$ splitting, which are regarded as benchmarks for the development of biomimetic and bioinspired catalysts for $\mathrm{H}_{2}$ production and/or uptake [76]. In this context, vibrational spectroscopy has greatly contributed to the understanding of hydrogenases, targeting inorganic cofactors, such as the particular catalytic site and Fe-S cluster relays, as well as organic protein cofactors (e.g., FAD and FMN) and certain adjacent protein residues (e.g., cysteine, glutamate) all involved in the biological $\mathrm{H}_{2}$ conversion [77]. Thereby, IR spectroscopy has played a major role in the characterization of these enzymes, which is related to the presence of the unusual inorganic carbon monoxide $(\mathrm{CO})$ and cyanide $\left(\mathrm{CN}^{-}\right)$ ligands coordinated to the particular active sites (Figure 6a) that exhibit characteristic IR bands in a spectral region free of other protein absorptions. Noteworthily, the specific band position of the $\mathrm{CO}\left(1780-2030 \mathrm{~cm}^{-1}\right)$ and $\mathrm{CN}^{-}\left(2030-2150 \mathrm{~cm}^{-1}\right)$ stretching modes (Figure $6 \mathbf{b}$, Table 1) are particularly sensitive to changes of the local protein environment, oxidation states of the metal centers, as well as external perturbations induced by changes of e.g., temperature and $\mathrm{pH}[78,79]$. Solution IR spectro-electrochemical studies [80] were thus extremely helpful for the structural and electronic characterization of the different redox states, providing key insights into the catalytic mechanism. Briefly, the [NiFe] hydrogenase catalytic cycle comprises four intermediates, i.e., $\mathrm{Ni}_{\mathrm{a}}-\mathrm{S}, \mathrm{Ni}_{\mathrm{a}}-\mathrm{L}, \mathrm{Ni}_{\mathrm{a}}-\mathrm{C}$, and $\mathrm{Ni}_{\mathrm{a}}$-SR differing in the oxidation state of nickel $\left(\mathrm{Ni}^{1+/ 2+/ 3+}\right)$ while iron retains a $\mathrm{Fe}^{2+} \mathrm{LS}$ configuration throughout the entire catalytic cycle. In the [FeFe] hydrogenase catalytic cycle, 
the di-iron center, $2 \mathrm{Fe}_{\mathrm{H}}$, has been isolated in a variety of intermediates, some of which are well understood $\left(\mathrm{H}_{\mathrm{ox}}, \mathrm{H}_{\text {red }} / \mathrm{H}_{\text {red }} \mathrm{H}^{+}, \mathrm{H}_{\text {hyd }}\right)$ while other presumed intermediates $\left(\mathrm{H}_{\text {red }}{ }^{\prime} \mathrm{H}\right.$, $\mathrm{H}_{\text {sred }}, \mathrm{H}_{\text {hyd }} \mathrm{H}^{+}, \mathrm{H}_{\mathrm{ox}} \mathrm{H}^{+}$) are still a subject of intense discussion [81,82]. For understanding the assignment of the catalytic competency of hydrogenase intermediates, a number of studies employing ATR-IR [22] and SEIRA [20] spectroscopy, both under controlled gas atmosphere or/and potential, photogating with time-resolved IR spectroscopy [83], and protein film IR electrochemistry (PFIRE) [21] have been performed.

a

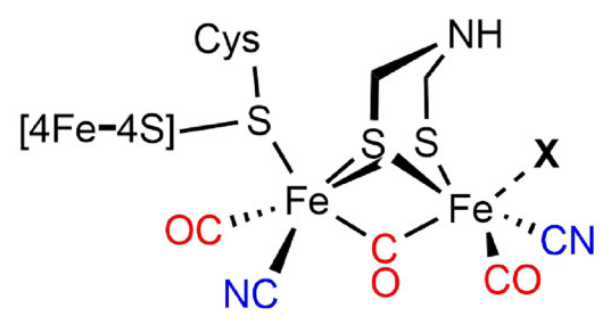

[FeFe]

\section{Hydrogenases}

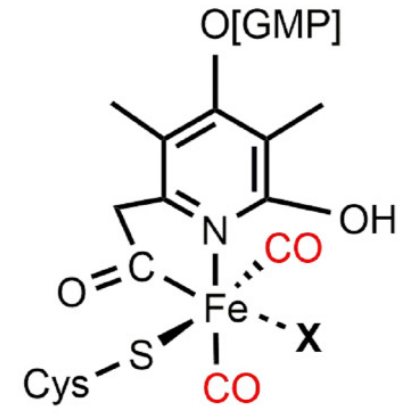

[Fe]

\section{b}

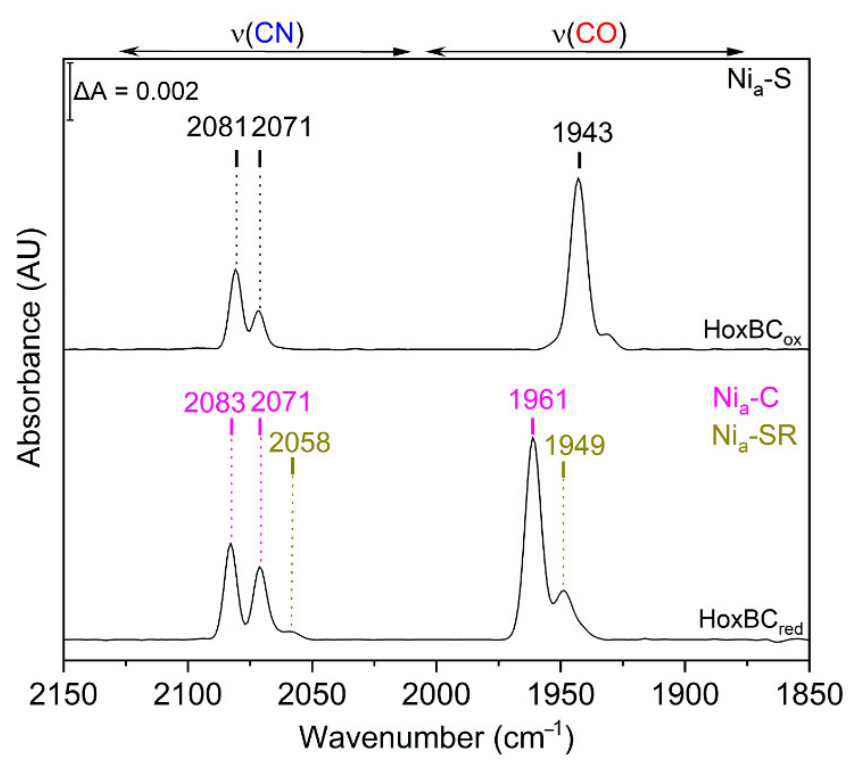

c

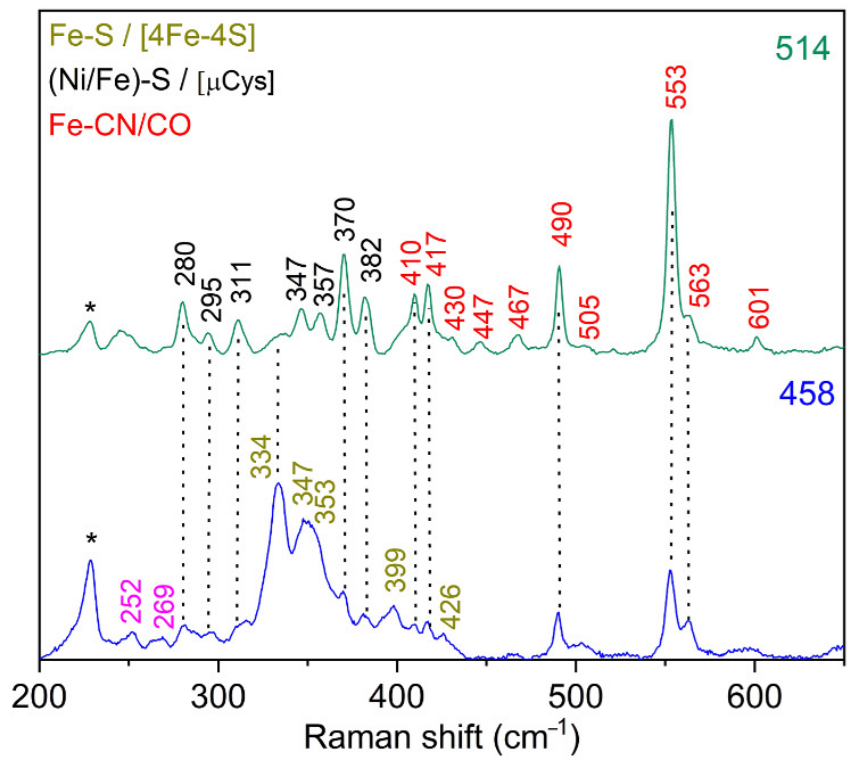

Figure 6. (a) Schematic representation of the active sites of [NiFe], [FeFe] and [Fe] hydrogenase. In [NiFe] hydrogenases, the nickel ion is coordinated by four cysteine residues, two of which are shared with the iron ion. One $\mathrm{CO}$ and $\mathrm{CN}^{-}$ligands complete the coordination sphere of the iron. In [FeFe] hydrogenases, the catalytic center is the H-cluster comprising a di-iron $\left(2 \mathrm{Fe}_{\mathrm{H}}\right)$ and a $[4 \mathrm{Fe}-4 \mathrm{~S}]_{\mathrm{H}}$ site sharing a cysteine coordination. Each iron of the $2 \mathrm{Fe}_{\mathrm{H}}$ is coordinated by one $\mathrm{CN}^{-}$and one $\mathrm{CO}$ ligand. A bridging $\mathrm{CO}$ and an azadithiolate ligand complete the $2 \mathrm{Fe}_{\mathrm{H}}$ coordination. In [Fe] hydrogenases, the single iron is coordinated by two CO ligands, a cysteine thiolate, and a guanylyl pyridinol cofactor bound to the iron via its acyl-carbon and pyridinol-nitrogen. Substrates and inhibitors bind at the coordination site marked by X. (b) IR spectra of as-isolated (top trace, $\mathrm{Ni}_{\mathrm{a}}-\mathrm{S}$ intermediate) and $\mathrm{H}_{2}$-reduced (bottom, $\mathrm{Ni}_{\mathrm{a}}-\mathrm{C}$ and $\mathrm{Ni}_{\mathrm{a}}-\mathrm{SR}$ intermediates) $\mathrm{RH}$ (HoxBC) at $283 \mathrm{~K}$ displaying the ligand stretching vibrations of the $\mathrm{CO}$ and $\mathrm{CN}^{-}$ligands of the active site, located between 1890 and $2000 \mathrm{~cm}^{-1}$ and 2030 and $2120 \mathrm{~cm}^{-1}$, respectively. (c) Low-temperature RR spectra at $80 \mathrm{~K}$ of the regulatory [NiFe] hydrogenase $(\mathrm{RH})$ recorded with excitation at 458 (blue trace) and 514 (green trace) $\mathrm{nm}$ in its as-isolated form. Color code of various metal ligand vibrations: Fe-CN/CO (red); Ni/Fe-S of bridging cysteines (black); Fe-S of [4Fe-4S] clusters (dark yellow). The lattice modes of ice are denoted by an asterisk $(*)$. 
Recently, ultrafast pump-probe and two-dimensional (2D) IR provided novel insights into the dynamic interactions between the hydrogenase $\mathrm{CO} / \mathrm{CN}^{-}$ligands and the complex interplay between the [NiFe] site and the protein scaffold [84]. Apart from the distinct $\mathrm{CO}$ and $\mathrm{CN}^{-}$markers bands, IR spectroscopy has also unveiled the participation of protein residues in the stabilization of certain intermediates. Combined IR difference spectroscopy and hydrogen/deuterium (H/D) isotopic labeling allowed for direct monitoring of the changes in the protonation state of conserved glutamate and arginine residues in both [NiFe] and [FeFe] hydrogenases [85]. Noteworthily, the IR detection of S-H/S-D stretching bands at $2505 \mathrm{~cm}^{-1}$ and $1822 \mathrm{~cm}^{-1}$, respectively, confirmed the protonation of a Ni-bound cysteine in the $\mathrm{Ni}_{\mathrm{a}}-\mathrm{L}$ intermediate.

Additional understanding of mechanistic properties of hydrogenases has been derived from RR spectroscopy that enables the detection of multiple protein cofactors. RR spectra of the F-420 [NiFe] hydrogenase revealed the spectral contributions of FAD, Fe-S clusters, and the [NiFe] active site [86]. Notably, $458 \mathrm{~nm}$ laser excitation preferentially enhanced the metal-ligand modes of the Fe-S clusters (Figure 6c, blue trace, Table 1), while the excitation lines distant from the $\mathrm{S} \rightarrow \mathrm{Fe} \mathrm{CT}$ transition resulted in a preferential enhancement of the active site vibrational modes (Figure $6 c$, green trace, Table 1) [87,88]. Supported by theoretical methods, RR spectroscopy has shown to be highly versatile in unraveling key electronic and structural details of the [NiFe] and [FeFe] bimetallic centers. Additionally, RR and IR spectroscopic studies were successfully performed on the same single hydrogenase crystals, complementing the crystallographic data and facilitating structural assignment of ambiguous inhibited and active redox states, such as the oxygen-stable $\mathrm{H}_{\text {inact }}$ and the hydrogen-binding intermediate $\mathrm{Ni}_{\mathrm{a}} \mathrm{S}$ state in $[\mathrm{FeFe}]$ and $[\mathrm{NiFe}]$ hydrogenases, respectively [86,89]. Notably, well-defined redox states in hydrogenase single crystals for IR imaging have been generated by electrochemical and gas control [90-93]. Furthermore, Fe-OH ligation at the unprecedented [4Fe-3S] cluster of the $\mathrm{O}_{2}$-tolerant membrane-bound [NiFe] hydrogenase from R. eutropha has been identified by RR spectroscopy and confirmed by theoretical quantum and molecular mechanics methods [94,95]. The corresponding $\mathrm{FeS}$ region of the three different clusters in the enzyme has been disentangled recently by RR spectroscopy in combination with protein engineering and X-ray crystallography [96], while its coupling with the physiological electron acceptor, cytochrome $b_{3}$, was investigated by SERR spectro-electrochemistry $[21,97]$.

\subsection{Multi-Cluster Containing Ferredoxins}

Ferredoxin, Fd, is a small ET protein that can have one or more Fe-S clusters and that takes part in a number of metabolic reactions. Multiple wavelength excitation of $\mathrm{Fe}-\mathrm{S}$ proteins that contain different clusters can assure selective RR enhancement of individual clusters and provide their independent monitoring. IR and RR spectroscopies of a Fd that houses one $[3 \mathrm{Fe}-4 \mathrm{~S}]^{1+/ 0}$ and one $[4 \mathrm{Fe}-4 \mathrm{~S}]^{2+/ 1+}$ center have addressed the effect of thermal perturbation on the level of secondary structural elements and the individual clusters, respectively. RR spectroscopy provided fine details about the disassembly of the centers in Fd, on the level of bridging and terminal Fe-S bonds of each cluster [98]. Three different laser excitation lines $(413,458$, and $514 \mathrm{~nm})$ were used to achieve a differential enhancement of the RR bands associated with [3Fe-4S] and [4Fe-4S] centers. For all three excitation wavelengths, the most prominent RR band is observed at $346 \mathrm{~cm}^{-1}$, which is a fingerprint of the $[3 \mathrm{Fe}-4 \mathrm{~S}]$ cluster bridging mode, $\left[3 \mathrm{Fe}-4 \mathrm{~S}^{\mathrm{B}}\right]$. Terminal vibrations of the same cluster, $\left[3 \mathrm{Fe}-4 \mathrm{~S}^{\mathrm{T}}\right]$, are found at $366 \mathrm{~cm}^{-1}$. The RR spectra recorded with $413 \mathrm{~nm}$ and $458 \mathrm{~nm}$ excitation show two additional features at $336 \mathrm{~cm}^{-1}$ and $358 \mathrm{~cm}^{-1}$ that are indicative of bridging and terminal modes of the [4Fe- $4 \mathrm{~S}]$ cluster, respectively $\left(\left[4 \mathrm{Fe}-4 \mathrm{~S}^{\mathrm{B}}\right]\right.$ and $\left.\left[4 \mathrm{Fe}-4 \mathrm{~S}^{\mathrm{T}}\right]\right)$. The spectral contributions of the clusters were accurately determined by applying band-fitting procedures. The intensity changes of the individual RR bands, i.e., $\left[3 \mathrm{Fe}-4 \mathrm{~S}^{\mathrm{B}, \mathrm{T}}\right]$ and $\left[4 \mathrm{Fe}-4 \mathrm{~S}^{\mathrm{B}, \mathrm{T}}\right]$, upon successive incubations of $\mathrm{Fd}$ at increasing temperatures revealed an apparent transition at around $53^{\circ} \mathrm{C}$ for all vibrational modes. The simultaneous degradation of the two metal centers follows the initial loss of the alfa helical structure 
and triggers major structural changes of the protein matrix, including the loss of tertiary contacts and a secondary structure reorganization that is consistent with the formation of a molten globule state, which could be assessed by IR spectroscopy [98].

\section{Outlook}

The continuous progress in experimental methodologies that ensure improved metalloprotein expression systems and purification and selective isotopic labeling methods, alongside the development of faster, more sensitive, and sophisticated vibrational spectroscopic techniques, allow us nowadays to study exceptionally complex, dynamic, and transient metal centers and processes in which they participate. For example, in the past few years, the synchrotron Mössbauer technique, nuclear resonance vibrational spectroscopy, NRVS, has greatly contributed to the understanding of iron dynamics in certain hydrogenase intermediates. Considerable achievements in particular resulted from the development of biochemical and chemical procedures enabling selective ${ }^{57}$ Fe-labeling exclusively at the [NiFe] and [FeFe] bimetallic centers [99,100]. Similarly, recent advances in femtosecond-stimulated Raman spectroscopy (FSRS), and in particular, the unique power of tunable FSRS to achieve different resonance conditions (i.e., FSRRS) and track various species and states of heme proteins, allow nowadays studies of protein dynamics and energy flow with femtosecond resolution [101,102]. To that end, well established RR, SERR, IR, and SEIRA spectroscopies, complemented with these more recently developed methods and theoretical calculations, have an unforeseen future in discovering new roles and physiologically relevant forms, metal centers with unique structures, and the processes that occur in multiple cofactor-containing metalloenzymes.

Author Contributions: Conceptualization, S.T.; writing-original draft preparation, S.T., C.M.S., L.Z. and G.C.; writing-review and editing, C.B., G.C., S.T., I.Z. and P.H.; supervision, S.T. and I.Z.; funding acquisition, S.T; C.M.S.; I.Z. and P.H. All authors have read and agreed to the published version of the manuscript.

Funding: This research was funded by FEDER funds through COMPETE2020-Programa Operacional Competitividade e Internacionalização (POCI) and by national funds through FCT—Fundacão para a Ciência e a Tecnologia, grant Project LISBOA-01-0145-FEDER-007660 (Microbiologia Molecular, Estrutural e Celular). S.T. acknowledges grant PTDC/BTM-SAL/29507/2017, C.M.S. acknowledges grant PTDC/BIA-BFS/31026/2017 project, and C.B. acknowledges fellowship 2020.05017.BD all funded by FCT. G.C., I.Z., and P.H. are grateful for funding from the Einstein Foundation Berlin (grant number EVF-2016-277). This work was also supported through the cluster of excellence "UniSysCat" funded by the Deutsche Forschungsgemeinschaft (DFG, German Research Foundation) under Germany's Excellence Strategy-EXC2008/1-390540038 and the SPP 1927 "Iron Sulfur for Life"-ZE 510/2-2 (IZ). The APC was funded by the TIMB3 project, European Union's Horizon 2020 research and innovation program, under grant agreement No 810856.

Institutional Review Board Statement: Not applicable.

Informed Consent Statement: Not applicable.

Data Availability Statement: Not applicable.

Conflicts of Interest: The authors declare no conflict of interest.

\section{References}

1. Siebert, F.; Hildebrandt, P. Vibrational Spectroscopy in Life Science; Wiley-VCH: Weinheim, Germany, 2008.

2. Czernuszewicz, R.S.; Fraczkiewicz, G.; Zareba, A.A. A Detailed Resonance Raman Spectrum of Nickel (II)-Substituted Pseudomonas aeruginosa Azurin. Inorg. Chem. 2005, 44, 5745-5752. [CrossRef]

3. Woodruff, W.H.; Spiro, T.G.; Yonetani, T. Resonance Raman Spectra of Cobalt-Substituted Hemoglobin: Cooperativity and Displacement of the Cobalt Atom upon Oxygenation. Proc. Natl. Acad. Sci. USA 1974, 71, 1065-1069. [CrossRef]

4. Woodruff, W.H.; Adams, D.H.; Spiro, T.G.; Yonetani, T. Resonance Raman spectra of cobalt myoglobins and cobalt porphyrins. Evaluation of protein effects on porphyrin structure. J. Am. Chem. Soc. 1975, 97, 1695-1698. [CrossRef] [PubMed]

5. Garton, S.D.; Garrett, R.M.; Rajagopalan, K.V.; Johnson, M.K. Resonance Raman Characterization of the Molybdenum Center in Sulfite Oxidase: Identification of MoO Stretching Modes. J. Am. Chem. Soc. 1997, 119, 2590-2591. [CrossRef] 
6. Todorovic, S.; Rodrigues, M.L.; Matos, D.; Pereira, I.A.C. Redox Properties of Lysine- and Methionine-Coordinated Hemes Ensure Downhill Electron Transfer in NrfH2A4 Nitrite Reductase. J. Phys. Chem. B 2012, 116, 5637-5643. [CrossRef] [PubMed]

7. Li, X.; Feng, M.; Wang, Y.; Tachikawa, A.H.; Davidson, V.L. Evidence for Redox Cooperativity between $c$-Type Hemes of MauG Which Is Likely Coupled to Oxygen Activation during Tryptophan Tryptophylquinone Biosynthesis. Biochemistry 2006, 45, 821-828. [CrossRef]

8. Pauleta, S.R.; Lu, Y.; Goodhew, C.F.; Qiu, Y.; Moura, I.; Pettigrew, G.; Shelnutt, J.A. Structural changes in the calcium-dependent activation of the di-heme cytochrome $c$ peroxidase of Paracoccus pantotrophus. Biophys. J. 2002, 82, 14A.

9. Wolf, M.W.; Rizzolo, K.; Elliott, S.J.; Lehnert, N. Resonance Raman, Electron Paramagnetic Resonance, and Magnetic Circular Dichroism Spectroscopic Investigation of Diheme Cytochrome $c$ Peroxidases from Nitrosomonas europaea and Shewanella oneidensis Biochemistry 2018, 57, 6416-6433. [CrossRef]

10. Hobbs, D.D.; Kriauciunas, A.; Güner, S.; Knaff, D.B.; Ondrias, M.R. Resonance Raman spectroscopy of cytochrome $b c 1$ complexes from Rhodospirillum rubrum: Initial characterization and reductive titrations. Biochim. Biophys. Acta Bioenerg. 1990, 1018, 47-54. [CrossRef]

11. Todorovic, S.; Teixeira, M. Resonance Raman spectroscopy of Fe-S proteins and their redox properties. JBIC J. Biol. Inorg. Chem. 2018, 23, 647-661. [CrossRef]

12. Qiu, C.; Cheng, Z.; Lv, C.; Wang, R.; Yu, F. Development of bioorthogonal SERS imaging probe in biological and biomedical applications. Chin. Chem. Lett. 2021. [CrossRef]

13. Cheng, Z.; Wang, R.; Xing, Y.; Zhao, L.; Choo, J.; Yu, F. SERS-based immunoassay using gold-patterned array chips for rapid and sensitive detection of dual cardiac biomarkers. Analyst 2019, 144, 6533-6540. [CrossRef]

14. Todorovic, S.; Murgida, D.H. Surface-Enhanced Raman Scattering of Biological Materials. In Encyclopedia of Analytical Chemistry; John Wiley \& Sons, Ltd.: Chichester, UK, 2016; pp. 1-29.

15. Sezer, M.; Millo, D.; Weidinger, I.; Zebger, I.; Hildebrandt, P. Analyzing the catalytic processes of immobilized redox enzymes by vibrational spectroscopies. IUBMB Life 2012, 64, 455-464. [CrossRef]

16. Todorovic, S.; Pereira, M.M.; Bandeiras, T.M.; Teixeira, M.; Hildebrandt, P.; Murgida, D.H. Midpoint Potentials of Hemes $a$ and $a_{3}$ in the Quinol Oxidase from Acidianus ambivalens are Inverted. J. Am. Chem. Soc. 2005, 127, 13561-13566. [CrossRef] [PubMed]

17. Hrabáková, J.; Ataka, K.; Heberle, J.; Hildebrandt, P.; Murgida, D.H. Long distance electron transfer in cytochrome $c$ oxidase immobilised on electrodes. A surface enhanced resonance Raman spectroscopic study. Phys. Chem. Chem. Phys. 2006, 8, 759-766. [CrossRef]

18. Behr, J.; Michel, H.; Mäntele, A.W.; Hellwig, P. Functional Properties of the Heme Propionates in Cytochrome $c$ Oxidase from Paracoccus denitrificans. Evidence from FTIR Difference Spectroscopy and Site-Directed Mutagenesis. Biochemistry 2000, 39, 1356-1363. [CrossRef] [PubMed]

19. Millo, D.; Pandelia, M.-E.; Utesch, T.; Wisitruangsakul, N.; Mroginski, M.A.; Lubitz, W.; Hildebrandt, P.; Zebger, I. Spectroelectrochemical Study of the [NiFe] Hydrogenase from Desulfovibrio vulgaris Miyazaki F in Solution and Immobilized on Biocompatible Gold Surfaces. J. Phys. Chem. B 2009, 113, 15344-15351. [CrossRef] [PubMed]

20. Wisitruangsakul, N.; Lenz, O.; Ludwig, M.; Friedrich, B.; Lendzian, F.; Hildebrandt, P.; Zebger, I. Monitoring Catalysis of the Membrane-Bound Hydrogenase from Ralstonia eutropha H16 by Surface-Enhanced IR Absorption Spectroscopy. Angew. Chem. Int. Ed. 2009, 48, 611-613. [CrossRef]

21. Hidalgo, R.; Ash, P.; Healy, A.J.; Vincent, K.A. Infrared Spectroscopy During Electrocatalytic Turnover Reveals the Ni-L Active Site State During H2 Oxidation by a NiFe Hydrogenase. Angew. Chem. Int. Ed. 2015, 54, 7110-7113. [CrossRef]

22. Senger, M.; Mebs, S.; Duan, J.; Wittkamp, F.; Apfel, U.-P.; Heberle, J.; Haumann, M.; Stripp, S.T. Stepwise isotope editing of [FeFe]-hydrogenases exposes cofactor dynamics. Proc. Natl. Acad. Sci. USA 2016, 113, 8454-8459. [CrossRef]

23. Martins, G.; Rodrigues, L.; Cunha, F.M.; Matos, D.; Hildebrandt, P.; Murgida, D.H.; Pereira, I.A.C.; Todorovic, S. Substrate Binding to a Nitrite Reductase Induces a Spin Transition. J. Phys. Chem. B 2010, 114, 5563-5566. [CrossRef]

24. Rinaldo, S.; Cutruzzolà, F. Chapter 3-Nitrite Reductases in Denitrification. In Biology of the Nitrogen Cycle; Bothe, H., Ferguson, S.J., Newton, W.E., Eds.; Elsevier: Amsterdam, The Netherlands, 2007; pp. 37-55.

25. Castiglione, N.; Rinaldo, S.; Giardina, G.; Stelitano, V.; Cutruzzolà, F. Nitrite and Nitrite Reductases: From Molecular Mechanisms to Significance in Human Health and Disease. Antioxid. Redox Signal. 2012, 17, 684-716. [CrossRef]

26. Cotton, T.M.; Timkovich, R.; Cork, M.S. Resonance Raman and surface-enhanced resonance Raman studies of cytochrome $c d 1$. FEBS Lett. 1981, 133, 39-44. [CrossRef]

27. Das, T.; Wilson, E.; Cutruzzola, F.; Brunori, M.; Rousseau, D.L. Binding of NO and CO to the $d 1$ Heme of $c d 1$ Nitrite Reductase from Pseudomonas aeruginosa. Biochemistry 2001, 40, 10774-10781. [CrossRef]

28. Silveira, C.M.; Quintas, P.O.; Moura, I.; Moura, J.J.G.; Hildebrandt, P.; Almeida, M.G.; Todorovic, S. SERR Spectroelectrochemical Study of Cytochrome $c d 1$ Nitrite Reductase Co-Immobilized with Physiological Redox Partner Cytochrome $c_{552}$ on Biocompatible Metal Electrodes. PLoS ONE 2015, 10, e0129940. [CrossRef]

29. Spiro, T.G.; Jarzecki, A.A. Heme-based sensors: Theoretical modeling of heme-ligand-protein interactions. Curr. Opin. Chem. Biol. 2001, 5, 715-723. [CrossRef]

30. Andrew, C.R.; George, S.; Lawson, D.M.; Eady, R.R. Six- to Five-Coordinate Heme-Nitrosyl Conversion in Cytochrome $c^{\prime}$ and Its Relevance to Guanylate Cyclase. Biochemistry 2002, 41, 2353-2360. [CrossRef] 
31. Quintas, P.; Catarino, T.; Todorovic, S.; Turner, D. Highly Selective Ligand Binding by Methylophilus methylotrophus Cytochrome $c^{\prime \prime}$. Biochemistry 2011, 50, 5624-5632. [CrossRef] [PubMed]

32. Gao, F.; Qin, H.; Knaff, D.; Zhang, L.; Yu, L.; Yu, C.; Gray, K.; Daldal, F.; Ondrias, M. Q-Band resonance Raman investigation of turnip cytochrome $f$ and Rhodobacter capsulatus cytochrome c1. Biochim. Biophys. Acta Protein Struct. Mol. Enzym. 1999, 1430, 203-213. [CrossRef]

33. De Vitry, C.; Desbois, A.; Redeker, V.; Zito, F.; Wollman, F.-A. Biochemical and Spectroscopic Characterization of the Covalent Binding of Heme to Cytochrome $b_{6}$. Biochemistry 2004, 43, 3956-3968. [CrossRef] [PubMed]

34. Picaud, T.; Le Moigne, C.; De Gracia, A.G.; Desbois, A. Soret-Excited Raman Spectroscopy of the Spinach Cytochrome $b_{6} f$ Complex. Structures of the $b$ - and $c$-Type Hemes, Chlorophylla, and $\beta$-Carotene. Biochemistry 2001, 40, 7309-7317. [CrossRef] [PubMed]

35. Bandeiras, T.M.; Refojo, P.; Todorovic, S.; Murgida, D.H.; Hildebrandt, P.; Bauer, C.; Pereira, M.M.; Kletzin, A.; Teixeira, M. The cytochrome $b a$ complex from the thermoacidophilic crenarchaeote Acidianus ambivalens is an analog of bc1 complexes. Biochim. Biophys. Acta Bioenerg. 2009, 1787, 37-45. [CrossRef]

36. Hellwig, P.; Grzybek, S.; Behr, J.; Ludwig, B.; Michel, H.; Mäntele, W. Electrochemical and ultraviolet/visible/infrared spectroscopic analysis of heme $a$ and $a_{3}$ redox reactions in the cytochrome $c$ oxidase from Paracoccus denitrificans: Separation of heme $a$ and $a_{3}$. Biochemistry 1999, 38, 1685-1694. [CrossRef] [PubMed]

37. Iwaki, M.; Giotta, L.; Akinsiku, A.O.; Schägger, H.; Fisher, N.; Breton, J.; Rich, P.R. Redox-Induced Transitions in Bovine Cytochrome $b c 1$ Complex Studied by Perfusion-Induced ATR-FTIR Spectroscopy. Biochemistry 2003, 42, 11109-11119. [CrossRef]

38. Iwaki, M.; Yakovlev, G.; Hirst, J.; Osyczka, A.; Dutton, P.L.; Marshall, D.; Rich, P.R. Direct Observation of Redox-Linked Histidine Protonation Changes in the Iron-Sulfur Protein of the Cytochrome bc1 Complex by ATR-FTIR Spectroscopy. Biochemistry 2005, 44, 4230-4237. [CrossRef] [PubMed]

39. Ferguson-Miller, S.; Babcock, G.T. Heme/Copper Terminal Oxidases. Chem. Rev. 1996, 96, 2889-2908. [CrossRef]

40. Uno, T.; Nishimura, Y.; Tsuboi, M.; Kita, K.; Anraku, Y. Resonance Raman study of cytochrome $b_{562}-0$ complex, a terminal oxidase of Escherichia coli in its ferric, ferrous, and CO-ligated states. J. Biol. Chem. 1985, 260, 6755-6760. [CrossRef]

41. Wang, J.; Rumbley, J.; Ching, Y.-C.; Takahashi, S.; Gennis, R.B.; Rousseau, D.L. Reaction of Cytochrome bo3 with Oxygen: Extra Redox Center(s) are Present in the Protein. Biochemistry 1995, 34, 15504-15511. [CrossRef]

42. Heibel, G.E.; Hildebrandt, P.; Ludwig, B.; Steinruecke, P.; Soulimane, T.; Buse, G. Comparative resonance Raman study of cytochrome $c$ oxidase from beef heart and Paracoccus denitrificans. Biochemistry 1993, 32, 10866-10877. [CrossRef]

43. Varotsis, C.; Babcock, G.T.; Garcia-Horsman, J.A.; Gennis, R.B. Resonance Raman Spectroscopy of the Heme Groups of Cytochrome $c b b_{3}$ in Rhodobacter sphaeroides. J. Phys. Chem. 1995, 99, 16817-16820. [CrossRef]

44. Pinakoulaki, E.; Pfitzner, U.; Ludwig, B.; Varotsis, C. The Role of the Cross-link His-Tyr in the Functional Properties of the Binuclear Center in Cytochrome $c$ Oxidase. J. Biol. Chem. 2002, 277, 13563-13568. [CrossRef] [PubMed]

45. Varotsis, C.; Vamvouka, M. Resonance Raman and Fourier Transform Infrared Detection of Azide Binding to the Binuclear Center of Cytochrome $b_{3}$ Oxidase from Escherichia coli. J. Phys. Chem. B 1999, 103, 3942-3946. [CrossRef]

46. Varotsis, C.; Vamvouka, M. Resonance Raman and FTIR Studies of Carbon Monoxide-Bound Cytochrome $a a_{3}-600$ Oxidase of Bacillus subtilis. J. Phys. Chem. B 1998, 102, 7670-7673. [CrossRef]

47. Oertling, W.A.; Surerus, K.K.; Einarsdóttir, Ó.; Fee, J.A.; Dyer, R.B.; Woodruff, W.H. Spectroscopic characterization of cytochrome $b a_{3}$, a terminal oxidase from Thermus thermophilus: Comparison of the $a_{3} / \mathrm{Cu}_{\mathrm{B}}$ site to that of bovine cytochrome a $a_{3}$. Biochemistry 1994, 33, 3128-3141. [CrossRef]

48. Varotsis, C.; Ohta, T.; Kitagawa, T.; Soulimane, T.; Pinakoulaki, E. The Structure of the Hyponitrite Species in a Heme Fe-Cu Binuclear Center. Angew. Chem. Int. Ed. 2007, 46, 2210-2214. [CrossRef] [PubMed]

49. Pinakoulaki, E.; Vamvouka, M.; Varotsis, C. Resonance Raman Detection of the $\mathrm{Fe}^{2+}-\mathrm{C}-\mathrm{N}$ Modes in Heme-Copper Oxidases: A Probe of the Active Site. Inorg. Chem. 2004, 43, 4907-4910. [CrossRef]

50. Egawa, T.; Lin, M.T.; Hosler, J.P.; Gennis, R.B.; Yeh, S.-R.; Rousseau, D.L. Communication between R481 and Cu in Cytochrome $\mathrm{bo}_{3}$ Ubiquinol Oxidase from Escherichia coli. Biochemistry 2009, 48, 12113-12124. [CrossRef]

51. Lauraeus, M.; Wikstrom, M.; Varotsis, C.; Tecklenburg, M.M.J.; Babcock, G.T. Optical and resonance Raman spectroscopy of the heme groups of the quinol-oxidizing cytochrome $a a_{3}$ of Bacillus subtilis. Biochemistry 1992, 31, 10054-10060. [CrossRef] [PubMed]

52. Wang, J.; Gray, K.A.; Daldal, F.; Rousseau, D.L. The $c b b_{3}$-Type Cytochrome $c$ Oxidase from Rhodobacter capsulatus Contains a Unique Active Site. J. Am. Chem. Soc. 1995, 117, 9363-9364. [CrossRef]

53. Ji, H.; Das, T.K.; Puustinen, A.; Wikström, M.; Yeh, S.-R.; Rousseau, D.L. Modulation of the active site conformation by site-directed mutagenesis in cytochrome $c$ oxidase from Paracoccus denitrificans. J. Inorg. Biochemistry 2010, 104, 318-323. [CrossRef]

54. Egawa, T.; Lee, H.J.; Gennis, R.B.; Yeh, S.-R.; Rousseau, D.L. Critical structural role of R481 in cytochrome $c$ oxidase from Rhodobacter sphaeroides. Biochim. Biophys. Acta Bioenerg. 2009, 1787, 1272-1275. [CrossRef]

55. Egawa, T.; Lee, H.J.; Ji, H.; Gennis, R.B.; Yeh, S.-R.; Rousseau, D.L. Identification of heme propionate vibrational modes in the resonance Raman spectra of cytochrome $c$ oxidase. Anal. Biochemistry 2009, 394, 141-143. [CrossRef]

56. Das, T.; Gomes, C.M.; Bandeiras, T.M.; Pereira, M.M.; Teixeira, M.; Rousseau, D.L. Active site structure of the $a a_{3}$ quinol oxidase of Acidianus ambivalens. Biochim. Biophys. Acta Bioenerg. 2004, 1655, 306-320. [CrossRef] 
57. Rousseau, D.L.; Han, S. 26-Time-Resolved Resonance Raman Spectroscopy of Intermediates in Cytochrome Oxidase. In Enzyme Kinetics and Mechanism; Purich, D.L., Ed.; Methods in Enzymology; Academic Press: Cambridge, MA, USA, 2002; Volume 354, pp. 351-368. [CrossRef]

58. Ogura, T.; Kitagawa, T. Resonance Raman characterization of the P intermediate in the reaction of bovine cytochrome $c$ oxidase. Biochim. Biophys. Acta Bioenerg. 2004, 1655, 290-297. [CrossRef] [PubMed]

59. Kitagawa, T. Structures of reaction intermediates of bovine cytochrome $c$ oxidase probed by time-resolved vibrational spectroscopy. J. Inorg. Biochem. 2000, 82, 9-18. [CrossRef]

60. Han, S.; Takahashi, S.; Rousseau, D.L. Time Dependence of the Catalytic Intermediates in Cytochrome $c$ Oxidase. J. Biol. Chem. 2000, 275, 1910-1919. [CrossRef] [PubMed]

61. Proshlyakov, D.A.; Pressler, M.A.; Babcock, G.T. Dioxygen activation and bond cleavage by mixed-valence cytochrome $c$ oxidase. Proc. Natl. Acad. Sci. USA 1998, 95, 8020-8025. [CrossRef]

62. Pinakoulaki, E.; Daskalakis, V.; Varotsis, C. The origin of the $\mathrm{Fe}^{\mathrm{IV}}=\mathrm{O}$ intermediates in cytochrome aa 3 oxidase. Biochim. Biophys. Acta Bioenerg. 2012, 1817, 552-557. [CrossRef] [PubMed]

63. Nyquist, R.M.; Heitbrink, D.; Bolwien, C.; Gennis, R.B.; Heberle, J. Direct observation of protonation reactions during the catalytic cycle of cytochrome $c$ oxidase. Proc. Natl. Acad. Sci. USA 2003, 100, 8715-8720. [CrossRef]

64. Todorovic, S.; Verissimo, A.; Wisitruangsakul, N.; Zebger, I.; Hildebrandt, P.; Pereira, M.M.; Teixeira, M.; Murgida, D.H. SERRSpectroelectrochemical Study of a $c b b_{3}$ Oxygen Reductase in a Biomimetic Construct. J. Phys. Chem. B 2008, 112, 16952-16959. [CrossRef]

65. Friedrich, M.G.; Giebeta, F.; Naumann, R.; Knoll, W.; Ataka, K.; Heberle, J.; Hrabakova, J.; Murgida, D.H.; Hildebrandt, P. Active site structure and redox processes of cytochrome $c$ oxidase immobilised in a novel biomimetic lipid membrane on an electrode. Chem. Commun. 2004, 2376-2377. [CrossRef] [PubMed]

66. Ataka, K.; Richter, B.; Heberle, J. Orientational Control of the Physiological Reaction of Cytochrome $c$ Oxidase Tethered to a Gold Electrode. J. Phys. Chem. B 2006, 110, 9339-9347. [CrossRef] [PubMed]

67. Sezer, M.; Woelke, A.-L.; Knapp, E.W.; Schlesinger, R.; Mroginski, M.A.; Weidinger, I. Redox induced protonation of heme propionates in cytochrome $c$ oxidase: Insights from surface enhanced resonance Raman spectroscopy and QM/MM calculations. Biochim. Biophys. Acta Bioenerg. 2017, 1858, 103-108. [CrossRef] [PubMed]

68. Hellwig, P.; Soulimane, T.; Mäntele, W. Electrochemical, FT-IR and UV/VIS spectroscopic properties of the $c a a_{3}$ oxidase from T. thermophilus. JBIC J. Biol. Inorg. Chem. 2002, 269, 4830-4838. [CrossRef] [PubMed]

69. Hellwig, P.; Gomes, C.M.; Teixeira, M. FTIR Spectroscopic Characterization of the Cytochrome aa 3 from Acidianus ambivalens: Evidence for the Involvement of Acidic Residues in Redox Coupled Proton Translocation. Biochemistry 2003, 42, 6179-6184. [CrossRef] [PubMed]

70. Stavrakis, S.; Pinakoulaki, E.; Urbani, A.; Varotsis, C. Fourier Transform Infrared Evidence for a Ferric Six-Coordinate Nitrosylheme $b_{3}$ Complex of Cytochrome $c b b_{3}$ Oxidase from Pseudomonas stutzeri at Ambient Temperature. J. Phys. Chem. B 2002, 106, 12860-12862. [CrossRef]

71. Koutsoupakis, C.; Kolaj-Robin, O.; Soulimane, T.; Varotsis, C. Probing Protonation/Deprotonation of Tyrosine Residues in Cytochrome $b a_{3}$ Oxidase from Thermus thermophilus by Time-resolved Step-scan Fourier Transform Infrared Spectroscopy. J. Biol. Chem. 2011, 286, 30600-30605. [CrossRef]

72. Gorbikova, E.A.; Vuorilehto, K.; Wikström, M.; Verkhovsky, M.I. Redox Titration of All Electron Carriers of Cytochrome $c$ Oxidase by Fourier Transform Infrared Spectroscopy. Biochemistry 2006, 45, 5641-5649. [CrossRef]

73. Melin, F.; Xie, H.; Meyer, T.; Ahn, Y.O.; Gennis, R.B.; Michel, H.; Hellwig, P. The unusual redox properties of $c$-type oxidases. Biochim. Biophys. Acta Bioenerg. 2016, 1857, 1892-1899. [CrossRef]

74. Pinakoulaki, E.; Varotsis, C. Resonance Raman Spectroscopy of Nitric Oxide Reductase and $c b b_{3}$ Heme-Copper Oxidase. J. Phys. Chem. B 2008, 112, 1851-1857. [CrossRef]

75. Lubitz, W.; Ogata, H.; Ruediger, O.; Reijerse, E. Hydrogenases. Chem. Rev. 2014, 114, 4081-4148. [CrossRef] [PubMed]

76. Kleinhaus, J.T.; Wittkamp, F.; Yadav, S.; Siegmund, D.; Apfel, U.-P. [FeFe]-Hydrogenases: Maturation and reactivity of enzymatic systems and overview of biomimetic models. Chem. Soc. Rev. 2021, 50, 1668-1784. [CrossRef]

77. Ash, P.A.; Hidalgo, R.; Vincent, K.A. Proton Transfer in the Catalytic Cycle of [NiFe] Hydrogenases: Insight from Vibrational Spectroscopy. ACS Catal. 2017, 7, 2471-2485. [CrossRef]

78. Caserta, G.; Pelmenschikov, V.; Lorent, C.; Waffo, A.F.T.; Katz, S.; Lauterbach, L.; Schoknecht, J.; Wang, H.; Yoda, Y.; Tamasaku, K.; et al. Hydroxy-bridged resting states of a [NiFe]-hydrogenase unraveled by cryogenic vibrational spectroscopy and DFT computations. Chem. Sci. 2021, 12, 2189-2197. [CrossRef]

79. Lorent, C.; Katz, S.; Duan, J.; Kulka, C.J.; Caserta, G.; Teutloff, C.; Yadav, S.; Apfel, U.-P.; Winkler, M.; Happe, T.; et al. Shedding Light on Proton and Electron Dynamics in [FeFe] Hydrogenases. J. Am. Chem. Soc. 2020, 142, 5493-5497. [CrossRef] [PubMed]

80. Corrigan, P.S.; Tirsch, J.L.; Silakov, A. Investigation of the Unusual Ability of the [FeFe] Hydrogenase from Clostridium beijerinckii to Access an $\mathrm{O}_{2}$-Protected State. J. Am. Chem. Soc. 2020, 142, 12409-12419. [CrossRef]

81. Rodríguez-Maciá, P.; Breuer, N.; Debeer, S.; Birrell, J.A. Insight into the Redox Behavior of the [4Fe-4S] Subcluster in [FeFe] Hydrogenases. ACS Catal. 2020, 10, 13084-13095. [CrossRef]

82. Land, H.; Senger, M.; Berggren, G.; Stripp, S.T. Current State of [FeFe]-Hydrogenase Research: Biodiversity and Spectroscopic Investigations. ACS Catal. 2020, 10, 7069-7086. [CrossRef] 
83. Greene, B.L.; Van Such, G.E.; Chica, B.C.; Adams, M.W.W.; Dyer, R.B. Applications of Photogating and Time Resolved Spectroscopy to Mechanistic Studies of Hydrogenases. Acc. Chem. Res. 2017, 50, 2718-2726. [CrossRef] [PubMed]

84. Horch, M.; Schoknecht, J.; Wrathall, S.L.D.; Greetham, G.M.; Lenz, O.; Hunt, N.T. Understanding the structure and dynamics of hydrogenases by ultrafast and two-dimensional infrared spectroscopy. Chem. Sci. 2019, 10, 8981-8989. [CrossRef]

85. Tai, H.; Hirota, S.; Stripp, S.T. Proton Transfer Mechanisms in Bimetallic Hydrogenases. Acc. Chem. Res. 2021, 54, $232-241$. [CrossRef]

86. Ilina, Y.; Lorent, C.; Katz, S.; Jeoung, J.H.; Shima, S.; Horch, M.; Zebger, I.; Dobbek, H. X-ray Crystallography and Vibrational Spectroscopy Reveal the Key Determinants of Biocatalytic Dihydrogen Cycling by [NiFe] Hydrogenases. Angew. Chem. Int. Ed. 2019, 58, 18710-18714. [CrossRef]

87. Katz, S.; Noth, J.; Horch, M.; Shafaat, H.S.; Happe, T.; Hildebrandt, P.; Zebger, I. Vibrational spectroscopy reveals the initial steps of biological hydrogen evolution. Chem. Sci. 2016, 7, 6746-6752. [CrossRef]

88. Horch, M.; Schoknecht, J.; Mroginski, M.A.; Lenz, O.; Hildebrandt, P.; Zebger, I. Resonance Raman Spectroscopy on [NiFe] Hydrogenase Provides Structural Insights into Catalytic Intermediates and Reactions. J. Am. Chem. Soc. 2014, 136, $9870-9873$. [CrossRef] [PubMed]

89. Rodríguez-Maciá, P.; Galle, L.M.; Bjornsson, R.; Lorent, C.; Zebger, I.; Yoda, Y.; Cramer, S.P.; Debeer, S.; Span, I.; Birrell, J.A. Caught in the $\mathrm{H}$ inact: Crystal Structure and Spectroscopy Reveal a Sulfur Bound to the Active Site of an $\mathrm{O}_{2}{ }^{-}$stable State of [FeFe] Hydrogenase. Angew. Chem. Int. Ed. 2020, 59, 16786-16794. [CrossRef]

90. Ash, P.A.; Carr, S.B.; Reeve, H.A.; Skorupskaitè, A.; Rowbotham, J.S.; Shutt, R.; Frogley, M.D.; Evans, R.M.; Cinque, G.; Armstrong, F.A.; et al. Generating single metalloprotein crystals in well-defined redox states: Electrochemical control combined with infrared imaging of a NiFe hydrogenase crystal. Chem. Commun. 2017, 53, 5858-5861. [CrossRef] [PubMed]

91. Morra, S.; Duan, J.; Winkler, M.; Ash, P.A.; Happe, T.; Vincent, K.A. Electrochemical control of [FeFe]-hydrogenase single crystals reveals complex redox populations at the catalytic site. Dalton Trans. 2021. [CrossRef]

92. Ash, P.A.; Kendall-Price, S.; Evans, R.M.; Carr, S.B.; Brasnett, A.; Morra, S.; Hidalgo, R.; Healy, A.J.; Cinque, G.; Frogley, M.; et al. The crystalline state as a dynamic system: IR microspectroscopy under electrochemical control for a [NiFe] hydrogenase. Chem. Sci. 2021. [CrossRef]

93. Lorent, C.; Pelmenschikov, V.; Frielingsdorf, S.; Schoknecht, J.; Caserta, G.; Yoda, Y.; Wang, H.; Tamasaku, K.; Lenz, O.; Cramer, S.P.; et al. Exploring Structure and Function of Redox Intermediates in [NiFe]-Hydrogenases by an Advanced Experimental Approach for Solvated, Lyophilized and Crystallized Metalloenzymes. Angew. Chem. Int. Ed. 2021, 60, 15854-15862. [CrossRef]

94. Siebert, E.; Rippers, Y.; Frielingsdorf, S.; Fritsch, J.; Schmidt, A.; Kalms, J.; Katz, S.; Lenz, O.; Scheerer, P.; Paasche, L.; et al. Resonance Raman Spectroscopic Analysis of the [NiFe] Active Site and the Proximal [4Fe-3S] Cluster of an $\mathrm{O}_{2}$-Tolerant MembraneBound Hydrogenase in the Crystalline State. J. Phys. Chem. B 2015, 119, 13785-13796. [CrossRef]

95. Frielingsdorf, S.; Fritsch, J.; Schmidt, A.; Hammer, M.; Löwenstein, J.; Siebert, E.; Pelmenschikov, V.; Jaenicke, T.; Kalms, J.; Rippers, Y.; et al. Reversible [4Fe-3S] cluster morphing in an $\mathrm{O}_{2}$-tolerant [NiFe] hydrogenase. Nat. Chem. Biol. 2014, 10, 378-385. [CrossRef]

96. Siebert, E.; Schmidt, A.; Frielingsdorf, S.; Kalms, J.; Kuhlmann, U.; Lenz, O.; Scheerer, P.; Zebger, I.; Hildebrandt, P. Resonance Raman spectroscopic analysis of the iron-sulfur cluster redox chain of the Ralstonia eutropha membrane-bound [NiFe]-hydrogenase. J. Raman Spectrosc. 2021. [CrossRef]

97. Sezer, M.; Frielingsdorf, S.; Millo, D.; Heidary, N.; Utesch, T.; Mroginski, M.-A.; Friedrich, B.; Hildebrandt, P.; Zebger, I.; Weidinger, I.M. Role of the HoxZ Subunit in the Electron Transfer Pathway of the Membrane-Bound [NiFe]-Hydrogenase fromRalstonia eutropha Immobilized on Electrodes. J. Phys. Chem. B 2011, 115, 10368-10374. [CrossRef] [PubMed]

98. Todorovic, S.; Leal, S.S.; Salgueiro, C.; Zebger, I.; Hildebrandt, P.; Murgida, D.H.; Gomes, C.M. A Spectroscopic Study of the Temperature Induced Modifications on Ferredoxin Folding and Iron-Sulfur Moieties. Biochemistry 2007, 46, 10733-10738. [CrossRef] [PubMed]

99. Caserta, G.; Lorent, C.; Pelmenschikov, V.; Schoknecht, J.; Yoda, Y.; Hildebrandt, P.; Cramer, S.P.; Zebger, I.; Lenz, O. In Vitro Assembly as a Tool to Investigate Catalytic Intermediates of [NiFe]-Hydrogenase. ACS Catal. 2020, 10, 13890-13894. [CrossRef] [PubMed]

100. Gilbert-Wilson, R.; Siebel, J.F.; Adamska-Venkatesh, A.; Pham, C.C.; Reijerse, E.; Wang, H.; Cramer, S.P.; Lubitz, W.; Rauchfuss, T.B. Spectroscopic Investigations of $[\mathrm{FeFe}]$ Hydrogenase Maturated with $\left[{ }^{57} \mathrm{Fe}_{2}(\mathrm{adt})(\mathrm{CN})_{2}(\mathrm{CO})_{4}\right]^{2-}$. J. Am. Chem. Soc. 2015, 137, 8998-9005. [CrossRef]

101. Brasseur, G.; Sariba, A.S.; Daldal, F. A compilation of mutation located in cytochrome $b$ subunit of the bacterial and mito-chondrial bc1 complex. Biochim. Biophys. Acta 1996, 1275, 61-69. [CrossRef]

102. Crofts, A.R.; Lhee, S.; Crofts, S.B.; Cheng, J.; Rose, S. Proton pumping in the bc1 complex: A new gating mechanism that prevents short circuits. Biochim. Biophys. Acta Bioenerg. 2006, 1757, 1019-1034. [CrossRef] [PubMed] 